Prepared in cooperation with the New York State Parks, Recreation, and Historic Preservation

\title{
Evaluating Legacy Effects of Hyperabundant White-Tailed Deer (Odocoileus virginianus) in Forested Stands of Harriman and Bear Mountain State Parks, New York
}

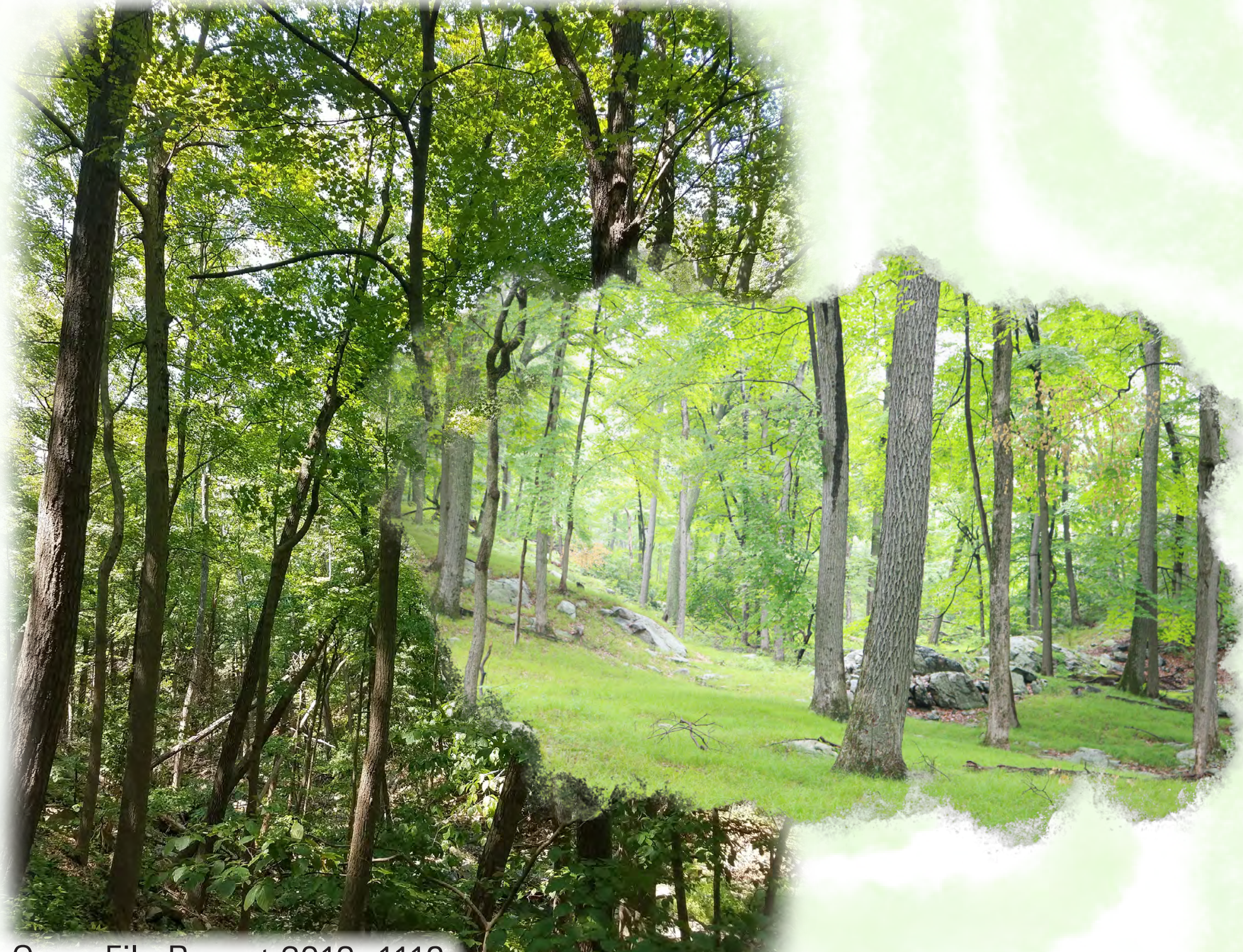

Open-File Report 2019-1116 2y.

U.S. Department of the Interior

U.S. Geological Survey 
Cover. (Left) Forest sapling layer at Black Rock Forest, where white-tailed deer are annually harvested, are dense and diverse; photograph by Chellby Kilheffer, State University of New York College of Environmental Science and Forestry. (Right) Forest sapling layer at Harriman and Bear Mountain State Parks are sparse and nearly nonexistent; photograph by Brian Underwood, U.S. Geological Survey. 


\section{Evaluating Legacy Effects of Hyperabundant White-Tailed Deer (Odocoileus virginianus) in Forested Stands of Harriman and Bear Mountain State Parks, New York}

By Chellby R. Kilheffer, H. Brian Underwood, Donald J. Leopold, and Rachel Guerrieri

Prepared in cooperation with the

New York State Parks, Recreation, and Historic Preservation

Open-File Report 2019-1116 


\title{
U.S. Department of the Interior DAVID BERNHARDT, Secretary
}

\author{
U.S. Geological Survey \\ James F. Reilly II, Director
}

\section{U.S. Geological Survey, Reston, Virginia: 2019}

For more information on the USGS - the Federal source for science about the Earth, its natural and living resources, natural hazards, and the environment-visit https://www.usgs.gov or call 1-888-ASK-USGS.

For an overview of USGS information products, including maps, imagery, and publications, visit https://store.usgs.gov.

Any use of trade, firm, or product names is for descriptive purposes only and does not imply endorsement by the U.S. Government.

Although this information product, for the most part, is in the public domain, it also may contain copyrighted materials as noted in the text. Permission to reproduce copyrighted items must be secured from the copyright owner.

Suggested citation:

Kilheffer, C.R., Underwood, H.B., Leopold, D.J., and Guerrieri, R., 2019, Evaluating legacy effects of hyperabundant white-tailed deer (Odocoileus virginianus) in forested stands of Harriman and Bear Mountain State Parks, New York: U.S. Geological Survey Open-File Report 2019-1116, 36 p., https://doi.org/10.3133/ofr20191116.

Associated data for this publication:

Kilheffer, C.R., Underwood, H.B., Leopold, D.J., and Guerrieri, R., 2019, Data collected for report entitled "Evaluating legacy effects of hyperabundant white-tailed deer in forested stands of Harriman and Bear Mountain State Parks, New York": State University of New York, College of Environmental Science and Forestry dataset, https://doi.org/10.7910/DVN/3ZFKFS.

ISSN 2331-1258 (online) 


\section{Acknowledgments}

We thank Mark Rogers, Edwin McGowan, Jesse Jaycox, Max Garfinkle, and Ron Rausch of the New York State Office of Parks, Recreation, and Historic Preservation for their help with field survey coordination, data compilation, historical context, and countless other logistics. We owe thanks to Matthew Brady, William Schuster, Francine Schuster, and Katie Terlizzi of Black Rock Forest for their assistance with site access, field surveys, plant identification, data compilation, and historical context of our study and other botanical studies conducted on the site. We also thank Chris Pray and Chris Killough of the West Point Military Reservation for their assistance with site access, field surveys, plant identification, data compilation, and historical context of our study. We are significantly indebted to Alex Petzke of the State University of New York College of Environmental Science and Forestry and Michael Hough of State University of New York Cortland for their assistance with identification of many graminoids encountered during field surveys. Thanks to Megan Kelley for her willingness to aid in field surveys. We also thank David Kramer and Jonathan Russell of the New York State Department of Environmental Conservation for obtaining, sharing, and interpreting town deer data used in this report. The reviews of Ed McGowan of the Palisades Interstate Park Commission and Mark Lesser of the State University of New York greatly improved a draft version of this report. 



\section{Contents}

Acknowledgments …........................................................................................................................

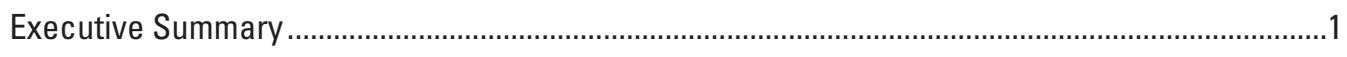

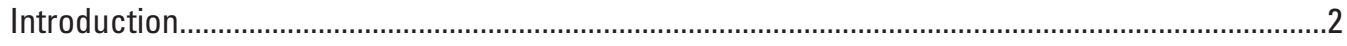

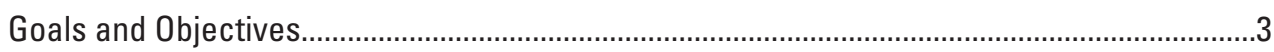

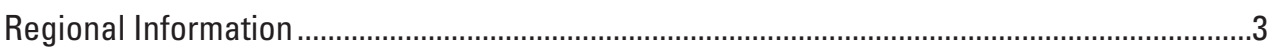

Control Sites: Harriman and Bear Mountain State Parks .....................................................

Case Sites: Sterling Forest State Park, Black Rock Forest, and West Point

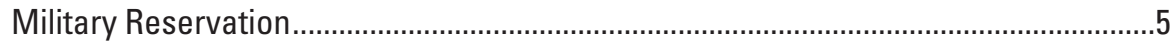

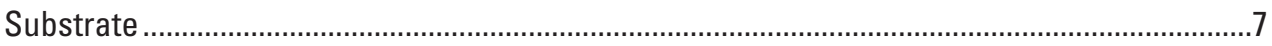

Community Type Descriptions ..........................................................................................

Appalachian Oak-Hickory Forest ..............................................................................

Chestnut Oak Forest ....................................................................................................

Hemlock-Northern Hardwood Forest..........................................................................

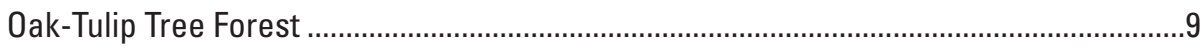

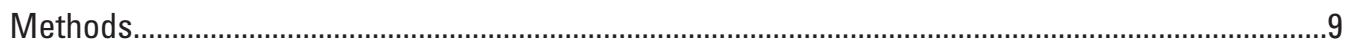

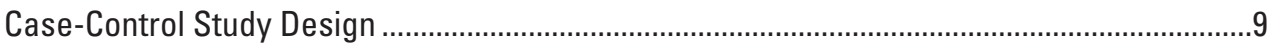

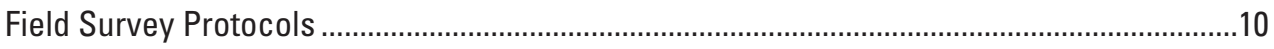

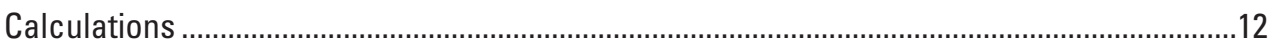

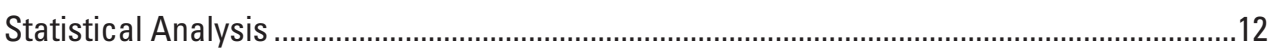

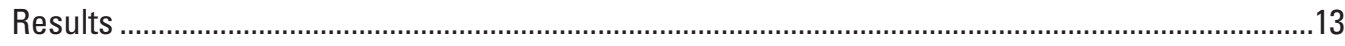

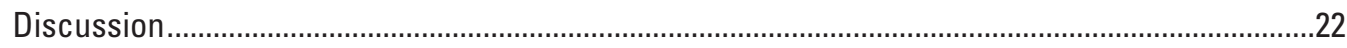

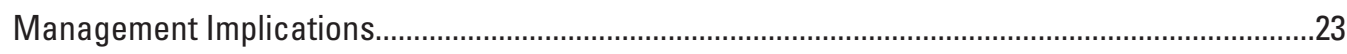

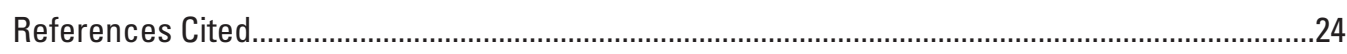

Appendix 1. Species Encountered in a Study of Hyperabundant White-Tailed Deer in

Forested Stands of Harriman and Bear Mountain State Parks, New York...........................32

\section{Figures}

1. Map showing the five study sites in the lower Hudson Valley, New York, where effects of white-tailed deer herbivory on forest understory and recruitment were assessed in 2018 .

2. Graph showing deer harvest for all towns (except Warwick) in the lower Hudson Valley, New York, that overlap study areas of Harriman, Bear Mountain, and Sterling Forest State Parks, Black Rock Forest, and West Point Military Reservation

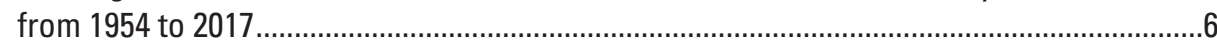

3. Graph showing deer harvest at Sterling Forest State Park, Black Rock Forest, and West Point Military Reservation, New York, from 1970 to 2017.

4. Maps showing $A$, aggregated soil types and $B$, dominant forest community types present at Harriman, Bear Mountain, and Sterling Forest State Parks, Black Rock Forest, and West Point Military Reservation in New York ...................................................8

5. Photograph showing canopy cover at a control plot in Harriman State Park, New York, photograph captured in 2018 with a smartphone and fish-eye lens..

6. Map showing locations of all plots surveyed among Harriman, Bear Mountain, and Sterling Forest State Parks, Black Rock Forest, and West Point Military Reservation in New York in summer 2018 to assess effects of white-tailed deer herbivory on forest vegetation 
7. Rose diagram showing slope and aspect of plots surveyed in the lower Hudson Valley, New York, to assess effects of white-tailed deer herbivory on forest vegetation.

8. Graphs showing mean and standard error of $A$, percent ground cover and $B$, proportion of plots containing each ground cover category between case and control sites surveyed in the lower Hudson Valley, New York, in 2018

9. Photograph showing a dense cluster of American beech (Fagus grandifolia) sprouts observed in Harriman State Park, New York, on August 10, 2018.

10. Map showing locations of trees cored at Harriman State Park, New York, in 2018 to assess the amount of time since last canopy recruitment

11. Photographs showing tree cores collected in $\mathbf{2 0 1 8}$ at Harriman State Park, New York

\section{Tables}

1. Forest communities present in selected areas surveyed in the lower Hudson Valley, New York, in 2018

2. Forest vegetation layer attributes to be calculated from field data collected among control and case sites in the lower Hudson Valley, New York, in 2018.

3. Plots surveyed in common forest community types in the Harriman, Bear Mountain, and Sterling Forest State Parks, Black Rock Forest, and West Point Military Reservation, New York, in 2018

4. Summary statistics between plots surveyed on case and control sites surveyed in the lower Hudson Valley, New York, in 2018.

5. Characteristics of trees between case and control sites surveyed in the lower Hudson Valley, New York, in 2018.

6. Characteristics of small trees and saplings between case and control sites surveyed in the lower Hudson Valley, New York, in 2018

7. Significant odds ratios from case-control conditional logistic regression for ground layer vegetation cover and occurrence surveyed among sites in the lower Hudson Valley, New York, in 2018.

8. Species, diameter at breast height, and estimated minimum age of all trees cored at Harriman State Park, New York, in 2018. 


\section{Conversion Factors}

International System of Units to U.S. customary units

\begin{tabular}{lcll}
\hline \multicolumn{1}{c}{ Multiply } & By & \multicolumn{1}{c}{ To obtain } \\
\hline centimeter $(\mathrm{cm})$ & 0.3937 & inch (in.) \\
meter $(\mathrm{m})$ & 3.281 & foot $(\mathrm{ft})$ \\
kilometer $(\mathrm{km})$ & 0.6214 & mile $(\mathrm{mi})$ \\
square meter $\left(\mathrm{m}^{2}\right)$ & 10.76 & square foot $\left(\mathrm{ft}^{2}\right)$ \\
hectare $(\mathrm{ha})$ & 2.471 & acre \\
\hline
\end{tabular}

\section{Datum}

Vertical coordinate information is referenced to the North American Vertical Datum of 1988 (NAVD 88).

Horizontal coordinate information is referenced to the North American Datum of 1983 (NAD 83).

Elevation, as used in this report, refers to distance above the vertical datum.

\section{Abbreviations}

$\begin{array}{ll}\text { AOHF } & \text { Appalachian oak-hickory forest } \\ \text { COF } & \text { chestnut oak forests } \\ \text { dbh } & \text { diameter at breast height } \\ \text { GIS } & \text { geographic information system } \\ \text { GLA } & \text { Gap Light Analyzer [software] } \\ \text { GLM } & \text { general linear model } \\ \text { GPS } & \text { Global Positioning System } \\ \text { HNHF } & \text { hemlock-northern hardwood forest } \\ \text { NLCD } & \text { National Land Cover Database } \\ \text { NYNHP } & \text { New York Natural Heritage Program } \\ \text { OTTF } & \text { oak-tulip tree forest } \\ \text { PCOM } & \text { point-centered quarter method }\end{array}$





\title{
Evaluating Legacy Effects of Hyperabundant White-Tailed Deer (Odocoileus virginianus) in Forested Stands of Harriman and Bear Mountain State Parks, New York
}

\author{
By Chellby R. Kilheffer, ${ }^{1}$ H. Brian Underwood, ${ }^{2}$ Donald J. Leopold, ${ }^{1}$ and Rachel Guerrieri'
}

\section{Executive Summary}

White-tailed deer (Odocoileus virginianus) are among the most impactful herbivores in the eastern United States. Legacy forest effects, those accrued from intense herbivory over time, manifest as low seedling regeneration, high cover of plant species that are infrequently browsed by deer, presence or expansion of nonnative or invasive plant species, few herbaceous species, and diminished capacity for recovery. Interfering vegetation (that is, species that increase in cover and density due to avoidance by deer, such as American beech sprouts, Pennsylvania sedge, and hay-scented fern) increase competition for light and hinder recruitment of trees into the forest canopy.

The lower Hudson Valley in New York has been heavily browsed by white-tailed deer since the early 20 th century. The region has some of the lowest tree regeneration rates in New York State as a result of deer browsing and subsequent increases in interfering vegetation. The U.S. Geological Survey and the State University of New York College of Environmental Science and Forestry studied sites where deer hunting is permitted (case sites) and nearby sites where hunting is currently prohibited (control sites) to assess and identify forest structure and composition differences.

Instead of using deer exclosures, which are time-consuming and expensive to install and maintain, we used a casecontrol study because such studies are well-suited to effects with long latency and rare outcomes. Case-control studies seek to describe the relation between an outcome of interest (in this study, forest understory recovery from chronic herbivory) and forest condition. We inferred recovery by comparing these characteristics on adjacent sites in the lower Hudson Valley with similar forest communities and land uses but different deer population management histories. Case plots were on lands where deer management has taken place annually for several decades. Control plots were on lands where deer

\footnotetext{
'State University of New York College of Environmental Science and Forestry.
}

${ }^{2}$ U.S. Geological Survey. populations have not been consistently managed to lowered abundance. We accounted for differences in forest recovery not attributable to deer by first matching case and control plots along several important environmental gradients (slope, aspect, elevation, moisture, canopy openness). By controlling for these gradients, we looked for associations between measured forest conditions and deer herbivory reduction through population management.

We surveyed more than 200 plots in upland forest types across case and control sites where we assessed forest condition by estimating density (number per unit area) and composition and cover (percent) of important vegetation constituents in ground, shrub, subcanopy, and canopy layers of the forest. We recorded 37 tree species, 22 shrub species, 57 herbaceous species, and 19 species of grasses and sedges in our plot surveys, including a number of nonnative and invasive plants. We also estimated the ages of a number of common canopy trees by counting rings from cores extracted from individual stems.

Effects of more than 100 years of chronic deer browsing manifested in low herbaceous ground cover and little to no tree recruitment (saplings) on lands without deer management. In contrast, sustained deer management resulted in forests with conditions that indicated substantial recovery from chronic herbivory in the ground, shrub, and subcanopy layers. Sites with ongoing deer management exhibited greater ground cover of tree seedlings and herbs and less ground cover of interfering vegetation and nonnative species. The well-developed subcanopy layer of small trees, saplings, and tall shrubs on sites with deer management indicates a high potential for sapling recruitment to the canopy of the future forest.

Of the 25 subcanopy trees sampled on control sites, most were more than 100 years old, indicating little to no regeneration in areas sampled for more than 100 years. The forest canopy, a relic of land uses of bygone days, requires a source of young trees to replace itself as older trees die. Without an abundant layer of young trees in the subcanopy, a forest cannot be sustained over time. Reduction in deer herbivory promotes forest recovery and could benefit Harriman and Bear Mountain State Parks (the control sites for the study), but removal of interfering vegetation may be necessary to mitigate legacy effects where they currently hinder ground 
layer recovery. To successfully promote a more desirable forest condition that includes elimination of nonnative plant species, promotion of tree recruitment into the forest canopy, and development of diverse and abundant herbaceous cover in ground layer vegetation, future management decisions could include information on herbivory reduction and management of interfering vegetation where necessary.

\section{Introduction}

The white-tailed deer (Odocoileus virginianus) is among the largest-bodied herbivores inhabiting the eastern deciduous forest and have the greatest effects on the ecosystem; the species effects on populations of plants and plant communities have been extensively reviewed (Russell and others, 2001; Rooney and Waller, 2003; Côté and others, 2004; Rawinski, 2016; McWilliams and others, 2018). In forested environments, selective foraging by deer frequently alters stand age structures, renders herbaceous layers susceptible to invasion by nonnative plant species, and homogenizes the flora by eliminating palatable and browse-intolerant plant species (Rooney and Waller, 2003; Sage and others, 2003; Eschtruth and Battles, 2009b; Tanentzap and others, 2011; Kalisz and others, 2014). The accumulated changes in forest stands ultimately cascade throughout the ecosystem and can have long-lasting effects (Nuttle and others, 2011; Pendergast and others, 2016; Brown and others, 2019).

Assessing the legacy effects of deer hyperabundance, those accrued from intense herbivory over time, can often be challenging (Royo and others, 2010) due to difficulty in capturing effects using traditional (exclosure) methods and complexity of interacting factors that are affected. In general, legacy effects include one or more of the following: (1) a dearth of advance tree seedling regeneration (Horsley and others, 2003), (2) a ubiquity of browse-tolerant, unpalatable, and undesired vegetation increasing competition for light (known as "interfering vegetation;" Sage and others, 2003; Nuttle and others, 2014), (3) the presence of nonnative or invasive plants (Bashant and others, 2005; Eschtruth and Battles, 2009a,b), (4) a depauperate and homogenized herb layer (Kain and others, 2011), and (5) diminished capacity for recovery by the soil seed bank despite reduced herbivory (Pendergast and others, 2016). Forest community type and species composition vary with site quality (McIntosh, 1962; Day and others, 1988; Russell and Schuyler, 1988; Glitzenstein and others, 1990; Rooney and Dress, 1997; Barringer and Clemants, 2003; Jelaska and others, 2006; Ward and others, 2013), factors of which (including soil type and depth, slope, and aspect) influence the kinds of effects likely to be expressed.

Management of the presence of interfering vegetation may also promote vigorous response of forest understory constituents to reduced deer herbivory (de la Cretaz and Kelty, 2002; Horsley and others, 2003; Sage and others, 2003; Steiner and others, 2008). For fully stocked forests, regeneration occurs predominantly in tree-fall canopy gaps or after a stand-altering disturbance like fire, wind throw, or logging (Lawton and Putz, 1988; Ward and others, 2013). In areas with high deer herbivory, abundance of interfering vegetation increases after a canopy disturbance and either directly or indirectly affects seedling germination, establishment, and growth (Horsley and Marquis, 1983; de la Cretaz and Kelty, 2002; Bashant and others, 2005). When canopy gaps are planned through forest management, treatment for interfering vegetation can precede tree removal to prevent effects of selective deer browsing on tree regeneration (Sage and others, 2003). In unmanaged forests, the pernicious effects of interfering vegetation may prevent achievement of desired future conditions even after deer reduction (Ward and others, 2013; Dey, 2014).

At broad spatial extents, strong negative correlations emerge between deer abundance and tree seedling density, diversity, cover, and growth (Habeck and Schultz, 2015; Russell and others, 2017), and effects of deer on forest tree regeneration vary by species (Lesser and others, 2019). These correlations have formed the basis for deer population management in forested environments for decades (Tierson and others, 1966; Behrend and others, 1970; Marquis and Brenneman, 1981; Tilghman, 1989; Horsley and others, 2003). Despite extensive deer population management actions throughout the species' range, the number of examples where herbivory reduction alone was sufficient to induce increases in cover of herb layer vegetation is relatively few (Royo and others, 2010; Urbanek and others, 2012; Jenkins and others, 2014). A recent meta-analysis showed variable and insignificant effect sizes of deer exclusion on herb layer characteristics (Habeck and Schultz, 2015), in part, due to replacement of native species by nonnative species and legacy effects of deer overabundance.

By far, the effects of herbivory on forest vegetation are most frequently deduced from deer exclosures (Underwood and others, 1994; Forrester and others, 2006; Averill and others, 2017; Kilheffer and others, 2019), which are time consuming and expensive to install and maintain. In our experience (see Kilheffer and others, 2019), use of deer exclosures is plagued by a number of limitations including lack of replication, pseudoreplication, insufficient sample size, and improper data analysis. The latter notwithstanding, the remaining deficiencies can be traced directly to the challenge and expense of building and maintaining fences in large forested tracts of land. In addition, elimination of deer herbivory through exclusion may create an artificial vegetation community that is exacerbated over time. Moreover, there is always a variable latency before differences in vegetation between inside and outside evince. Consequently, we sought an alternative to traditional exclosure studies for assessing biotic effects of deer herbivory.

For this report, we used a study design similar to one commonly used in epidemiology called a case control (Carlson and Morrison, 2009; Pearce, 2016). A case control is a retrospective, observational study that compares a population of subjects with a common exposure, some with the outcome 
of interest (cases) and others without it (controls). Analyses of case-control studies seek to describe the relation between the outcome of interest and a set of prognostic variables (Pearce, 2016). In the present context, the outcome of interest is forest recovery from chronic herbivory predicted from characteristics measured at sites with deer management (case sites: Sterling Forest State Park, Black Rock Forest, and West Point Military Reservation) and where deer harvest is prohibited (control sites: Harriman and Bear Mountain State Parks; fig. 1). We infer recovery by comparing these attributes in adjacent sites with similar forest communities and land uses but differing deer population management histories. A casecontrol approach to studying the biotic effects of deer herbivory offers several advantages over traditional exclosure studies that warrant further investigation.

The forests in southeastern New York State have been heavily browsed by white-tailed deer for nearly a century (Leopold and others, 1947; McWilliams and others, 2018), invaded by nonnative plants, and have shown limited regeneration of several dominant canopy species (Shirer and Zimmerman, 2010). The lower Hudson Valley has some of the lowest regeneration rates in New York as a result of deer browsing and interfering vegetation (Connelly and others, 2010). The dominant forest types in this region contain high proportions of oaks (Quercus spp.), maples (Acer spp.), and birches (Betula spp.), each of which is susceptible to white-tailed deer herbivory (McWilliams and others, 2018). The New York Natural Heritage Program (NYNHP) completed and updated maps of forest communities in New York State, including those of State parks in the lower Hudson Valley. The NYNHP descriptions included species composition of canopy and understory, shrub cover, and ground cover (Edinger and others, 2014), though little information is maintained about the status of these forests in terms of desired future conditions (Largay and Sneddon, 2007). Throughout this report, we use nomenclature published by the Natural Resources Conservation Service (2018) plants database.

\section{Goals and Objectives}

The overarching goal of this study was to assess and identify forest structure and composition differences in the lower Hudson Valley region among sites where hunting of white-tailed deer is prohibited and where hunting is permitted. Our purpose is to evaluate the long-term (100-year) implications of deer management to the biological integrity and forest recovery prospects for Harriman and Bear Mountain State Parks, which lie within a New York State biological diversity hotspot. Specific research objectives include (1) implementation of a matched case-control study of the effects of deer herbivory based on plot sampling of common forest community attributes during the summer of 2018 and (2) assessment of the ecological condition of the dry oak forest relative to current and legacy effects of chronic herbivory.

\section{Regional Information}

The lower Hudson Valley region of New York is approximately 60 kilometers $(\mathrm{km})$ northwest of New York City and includes several of New York's State parks (fig. 1; Evans and VanLuven, 2007). The region contains the largest tract of contiguous chestnut oak forest in New York, exhibits high biodiversity, and has particularly high human development pressure (Evans and VanLuven, 2007; New York State Office of Parks, Recreation, and Historic Preservation, 2016). Most of the remaining core forest (Harriman, Bear Mountain, and Sterling Forest State Parks) in the region (Widmann and others, 2015) is protected as State park land. The topography is rugged and mountainous, with steep slopes and summits 300 to 430 meters (m) in elevation (New York State Forest, Fish, and Game Commission, 1910). Human recreation rates are high (Maher, 1999; New York State Office of Parks, Recreation, and Historic Preservation, 2018) due to the area's dense local human populations, close proximity to New York City, and historically reliable transportation systems (New York State Forest, Fish, and Game Commission, 1910).

The land use history of forests in this region of the United States is complex and heavily affected by human activities (Spurr, 1956). Before European settlement, indigenous peoples used controlled fires to maintain grasslands, promote mast tree growth, and provide browse for white-tailed deer for hunting purposes (Abrams and Nowacki, 2008). Through much of the 19th century, charcoal furnaces used to smelt iron ore from bedrock were fueled through logging of all nearby trees (Russell and Schuyler, 1988; Whitney, 1994). Constant cutting and burning created conditions that favored dry oak forest communities like those present in much of southeastern New York today (Edinger and others, 2014). In the early 1900s, forest canopies in this region were dominated (35 percent) by American chestnut (Castanea dentata; New York State Forest, Fish, and Game Commission, 1910). The introduction of chestnut blight (Cryphonectria parasitica) in the early 20th century eliminated American chestnut trees as a major constituent of the canopy, further changing forest composition in the region. Most clearcut lands were abandoned and allowed to regenerate as industry left the area in the early 20th century (Russell and Schuyler, 1988; Glitzenstein and others, 1990).

Current forest associations result from the interactions of several factors, including migration of tree species, precolonial distribution of species, land-use history, soil conditions, depth to water table, aspect, elevation, local climate, insects, pathogens, fire regime, herbivory, and storms (Spurr, 1956; McEwan and others, 2011). When forest burning was frequent, white oak (Q.alba) thrived, and northern red oak (Q. rubra) trees were limited by their low tolerance to fire and drought. Growth of northern red oak and chestnut oak (Q. montana) were promoted after effects of white-tailed deer began to limit the regeneration of white oak (Q. alba; Abrams, 2003). After burning ceased, mesic conditions became more prevalent in the northeast region (Nowacki and Abrams, 2015). In the complete absence of fire, oak regeneration is limited, allowing 


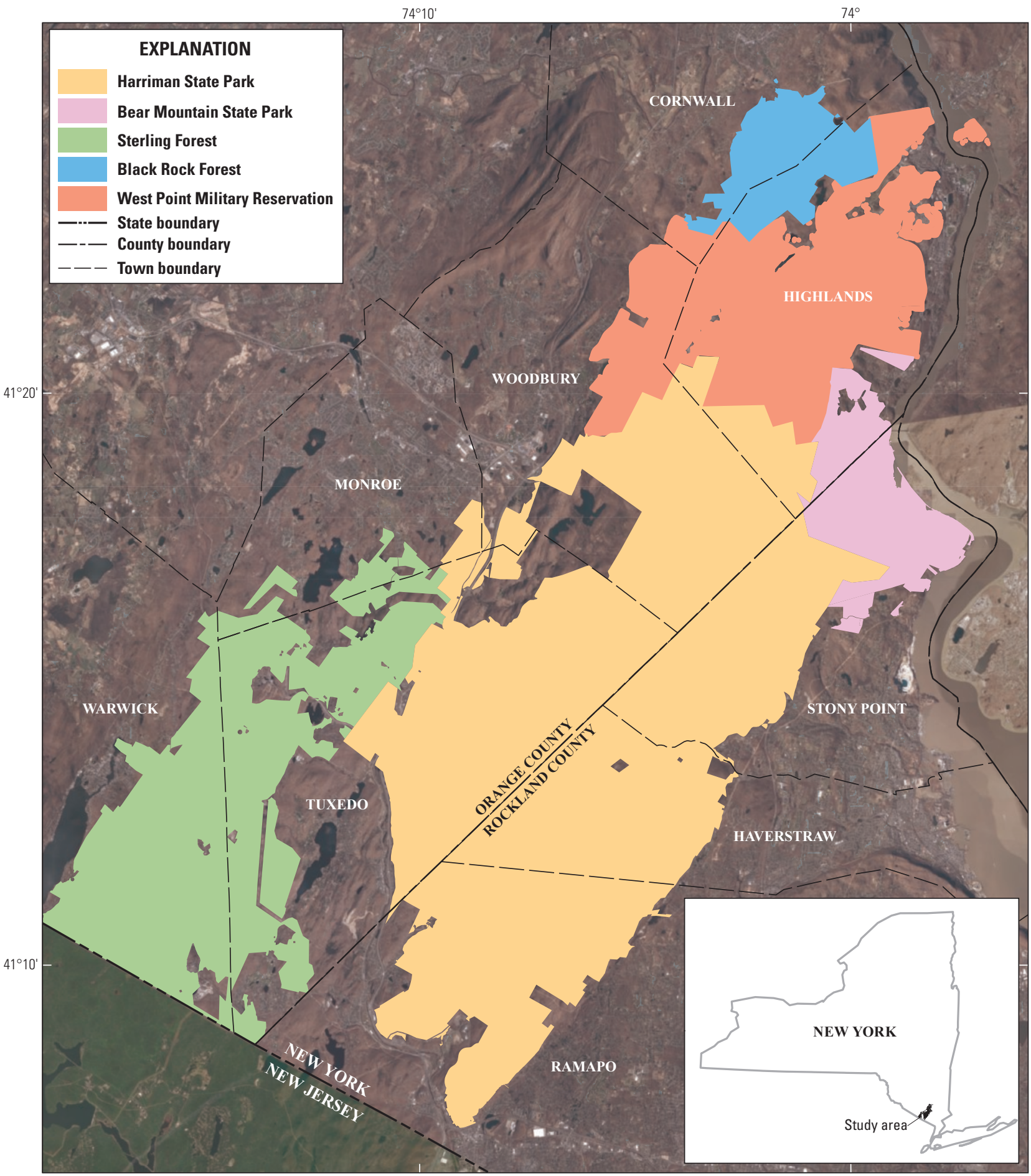

Base map is copyright Esri, Inc. and its licensors; used under license, 2018.

State, county, and town boundaries mapped by the New York State GIS Clearinghouse, 2018

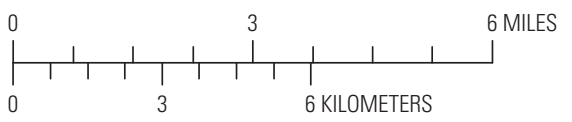

Figure 1. The five study sites in the lower Hudson Valley, New York, where effects of white-tailed deer herbivory on forest understory and recruitment were assessed in 2018. Deer hunting is prohibited at Harriman State Park and Bear Mountain State Park, but is annually regulated at Sterling Forest State Park, Black Rock Forest, and West Point Military Reservation. 
fire-intolerant species such as red maple (A. rubrum), sweet birch (B. lenta), and tulip tree (Liriodendron tulipifera) to thrive and ultimately change the forest composition in previously oak-dominated forests (Russell and Schuyler, 1988; Abrams, 2003; Fei and Steiner, 2007; Nowacki and Abrams, 2008; Elliott and Vose, 2011). Due to changes in climate and disturbance regime, previously oak-dominated forests can transition into more, mixed hardwood forests featuring increasingly greater cover of shade-tolerant species over time (Hanberry and others, 2012).

Many shade-tolerant, mesophytic species like maples, birches, tulip tree, American beech (Fagus grandifolia), sassafras (Sassafras albidum) and gums (Nyssa spp.) are more sensitive to changes in precipitation than oak species (Klos and others, 2009; Elliott and others, 2015; Roman and others, 2015). Consequently, changes in forest structure from mainly oaks to maples alter hydrology, nutrient availability, and decomposition rates (Dey, 2002; Knoepp and others, 2005; Ball and others, 2009; Alexander and Arthur, 2010; Keiser and others, 2013).

White-tailed deer were nearly extirpated from New York by the late-1800s due to land clearing and unregulated harvest (Severinghaus and Brown, 1956; McCabe and McCabe, 1984). As poor farm lands were abandoned in the early 1900s, deer began to recolonize their former range. Deer populations dramatically increased in southern counties of New York duringthe 1920s and reached "chronic" levels by 1931 (Leopold and others, 1947). By winter 1939-40, the population increased to the point that many deer were found dead of starvation in Bear Mountain and Harriman State Parks (Severinghaus and Brown, 1956). Similar to other protected deer herds in New York (Underwood and Porter, 1997), the deer population of Harriman and Bear Mountain State Parks likely irrupted due to their protected status and favorable habitat resulting from land-use changes. Because deer hunting is permitted in most towns in Orange and Rockland Counties but not permitted in Harriman and Bear Mountain State Parks, park lands likely serve as a refuge and population source for the surrounding towns.

\section{Control Sites: Harriman and Bear Mountain State Parks}

Harriman (19,266 hectares [ha]) and Bear Mountain (2,156 ha) State Parks are located in southeastern New York (fig. 1). Both parks are owned and managed by the Palisades Interstate Park Commission, a governing body created at the turn of the 20th century to protect the area from booming industry. Before the parks were established, most of the land was privately owned and forested. The forests were typically of poor quality due to constant clearcutting and forest fires (Moon, 1910). Harriman State Park was established in 1910, and Bear Mountain State Park was established in 1913. Some forested areas were cleared for development of facilities, roads, and trails. In addition, several dams were constructed from shortly after park establishment until the 1940s and their use continues to this day (New York State Department of Environmental Conservation, 2009), flooding several hundred acres of forest to construct lakes for recreational purposes. Park managers began a forest management program in 1914 that included removal of dying chestnut trees and plantings of other tree species. Park managers also began implementing fire prevention methods in the 1910s (Maher, 1994). Before 2009, an unwritten policy prohibited commercial logging on State park lands; a formal policy was adopted in 2009. This policy included strict limitations on the removal of trees and other vegetation (New York State Office of Parks, Recreation, and Historic Preservation, 2009).

Hunting of white-tailed deer is currently not permitted in Bear Mountain State Park. Hunting is permitted on a small segment of Harriman State Park that is contiguous with Sterling Forest State Park (shotgun: 559 ha, archery: 200 ha). Deer hunting was permitted on 10,000 acres (4,047 ha) of Harriman State Park during a 3-year pilot program in the early 1980 s to reduce effects of white-tailed deer on forests, but was halted after 1983 due to legal challenges (Hudson, 1983). Deer hunting has been permitted in many of the nearby towns for more than 50 years and is regulated by the New York State Department of Environmental Conservation (2018). Hunter effort and deer harvest vary among towns (fig. 2). The numbers of deer harvested in the town of Warwick are greater $(>1,000$ deer per year) than in any other town due to the much larger size and high proportion of State forest lands in Warwick (D. Kramer, New York State Department of Environmental Conservation, oral commun., 2018); therefore, we do not consider deer harvest in Warwick in this report.

On our control sites, all located within Harriman and Bear Mountain State Parks, we expected high proportions of ground cover of plant species less preferred or avoided by deer. Pennsylvania sedge (Carex pensylvanica) and hay-scented fern (Dennstaedtia punctilobula) become interfering vegetation as a result of white-tailed deer herbivory in northeastern forests because they are often not browsed (McCormick and others, 1992; Augustine and McNaughton, 1998; Comiskey and Wakamiya, 2011) and they proliferate when browse-intolerant species are reduced (de la Cretaz and Kelty, 2002; Carson and others, 2005; Holdsworth and others, 2007). We also expected greater cover and diversity of invasive nonnative plants (Latham and others, 2005; Duguay and Farfaras, 2011) because they are typically not browsed by white-tailed deer.

\section{Case Sites: Sterling Forest State Park, Black Rock Forest, and West Point Military Reservation}

Sterling Forest State Park (7,751 ha) was established as a State park in 1998. White-tailed deer hunting at Sterling Forest State Park is currently regulated by the New York State Office of Parks, Recreation, and Historic Preservation. Before 


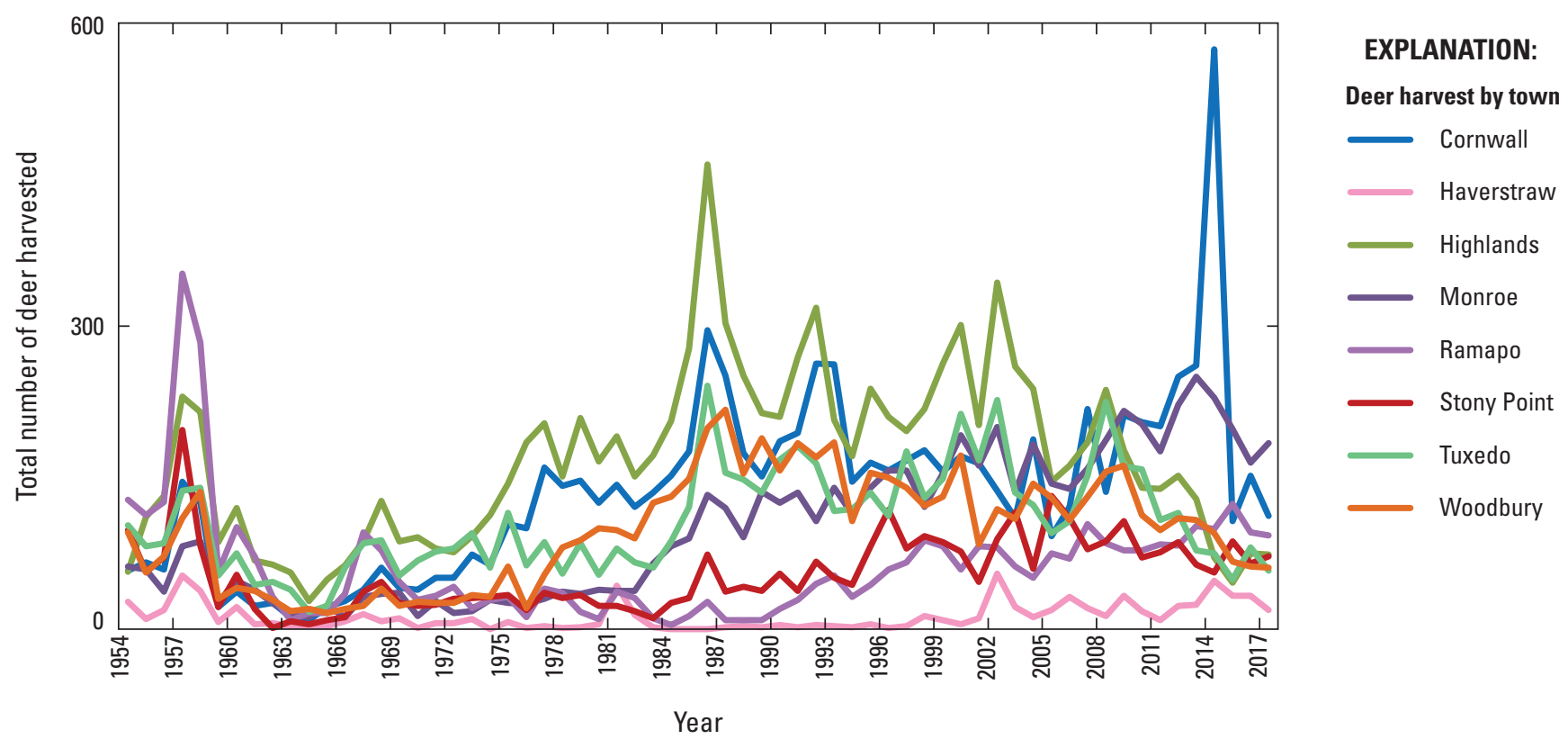

Figure 2. Deer harvest for all towns (except Warwick) in the lower Hudson Valley, New York, that overlap study areas of Harriman, Bear Mountain, and Sterling Forest State Parks, Black Rock Forest, and West Point Military Reservation from 1954 to 2017. Data are from New York State Department of Environmental Conservation deer take summaries (New York State Department of Environmental Conservation, 2018).

becoming a State park, the lands were managed by the Sterling Forest Corporation, which allowed recreational hunting until 1968, at which time it initiated a deer management program due to effects of deer herbivory on forest condition (M. Garfinkle, New York State Office of Parks, Recreation, and Historic Preservation, oral commun., 2018). Early harvests across the entire property ranged from 75 to 110 deer per year (J. Hutchinson, New York State Office of Parks, Recreation, and Historic Preservation, oral commun., 2018), though only recent harvest counts are available (fig. 3).

Black Rock Forest (1,574 ha), formerly a family estate, was established as an experimental forest in 1928. Only

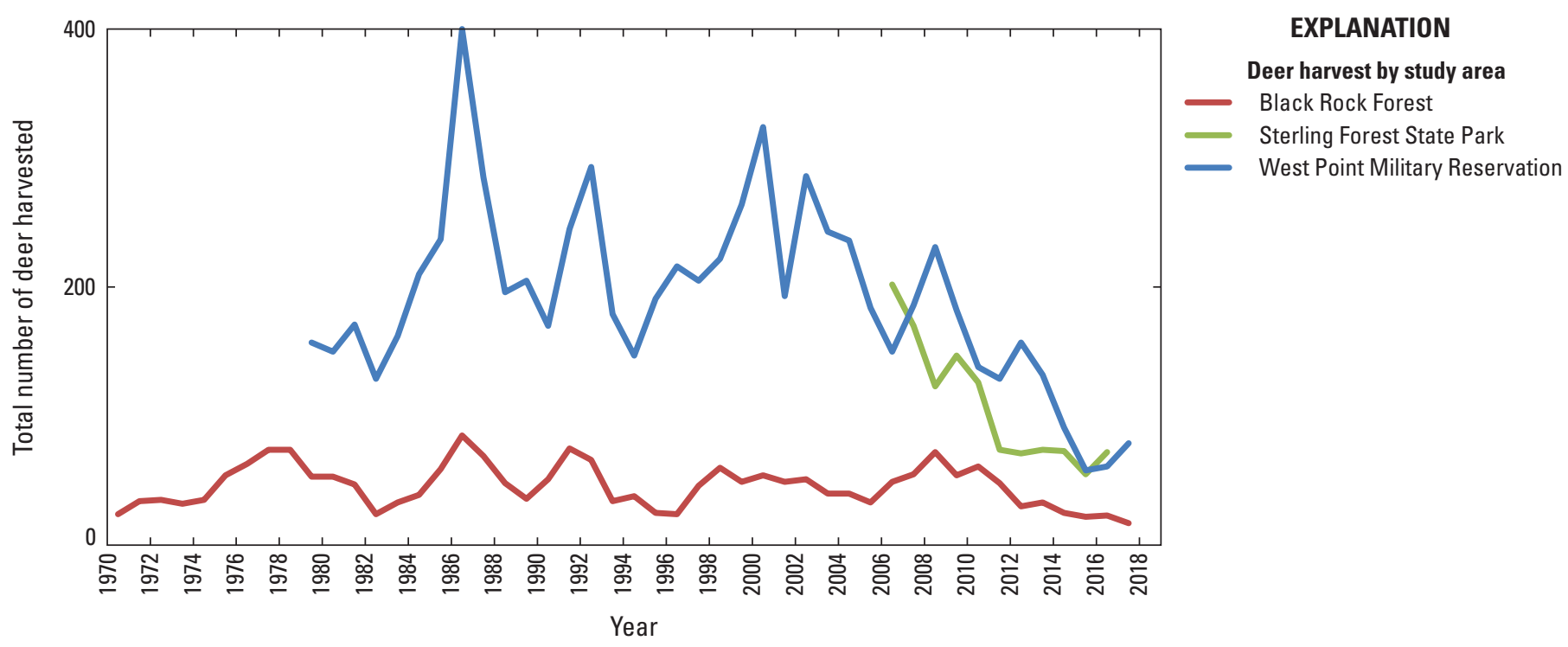

Figure 3. Deer harvest at Sterling Forest State Park, Black Rock Forest, and West Point Military Reservation, New York, from 1970 to 2017. Data are from the New York State Office of Parks, Recreation, and Historic Preservation, Black Rock Forest, and West Point Military Reservation. 
7.5 percent of the land that became Black Rock Forest was used, at any time, for agriculture due to the poor quality of the soils and the steep topography (Maher, 1999). Recreational hunting was allowed at Black Rock Forest until 1970, when a regulated hunting program was initiated to reduce biotic effects of white-tailed deer to forest integrity (W. Schuster, Black Rock Forest, oral commun., 2018). Experimental cuttings and plantings were done on Black Rock Forest until the 1980s when 15 scientific and educational institutions created the Black Rock Forest Consortium, tasked with managing the Black Rock Forest property (Barringer and Clemants, 2003). Using data from 1930 to 2000, Schuster and others (2008) identified shifts in tree community composition from mixed oak-maple to red maple-sweet birch, a decrease in tree density from about 1,500 to 735 trees per hectare, and an increase in basal area from $<15$ to 30 square meters per hectare. In a case study at Black Rock Forest, exclosures revealed that deer slowed or suspended forest succession by preventing regeneration of palatable species (Ballantyne, 2000), although differences in species diversity and biomass were not significantly different after exclusion (Wayne, 2014).

The West Point Military Reservation (5,551 ha) was established as a commanding position during the American Revolution and became a military academy in 1802. Deer hunting has been permitted on the West Point Military Reservation annually since 1979 in an effort to halt undesirable forest changes resulting from excessive deer browsing (C. Pray, West Point Military Reservation, oral commun., 2018). Investigations at the West Point Military Reservation indicate that white-tailed deer are detrimental to forest tree regeneration and understory herbaceous plant diversity and have induced shifts in plant species communities over time (Blossey and others, 2017). Interactive effects among white-tailed deer, invasive earthworms, root weevils (Barypeithes pellucidus), and nonnative plants including Japanese barberry (Berberis thunbergii) and Japanese stiltgrass (Microstegium vimineum) influence understory plant communities in forested areas at the West Point Military Reservation (Dávalos and others, 2015; Blossey and others, 2017; Nuzzo and others, 2017).

\section{Substrate}

Substrate and bedrock greatly influence forest species composition (Russell and Schuyler, 1988). The highlands are predominantly granitic gneiss and granite ridges (New York State Forest, Fish, and Game Commission, 1910; Barringer and Clemants, 2003), rock outcrops are very common, and concentrations of iron ore are often high. Most soils are very thin and poorly drained. Substrate type is often sandy loam with high proportions of gravel. Any areas of reasonable productivity were likely historically used for agriculture, though most were abandoned during the 19th century (New York State Forest, Fish, and Game Commission, 1910).

The most common soil types present in our study sites include Alden soils, Charlton-rock outcrops, gravelly loams,
Hollis soils, a combination of rock outcrops and Hollis complex, Erie stony soils, and moist soils (fig. 4A; Natural Resources Conservation Service, 2017). Alden soils are very deep and poorly drained and found in depressions and low areas. Slopes range from 0 to 3 percent, elevation ranges from 90 to $455 \mathrm{~m}$, and available water capacity is high. Charlton soils are very deep, well-drained, and often stony. Charlton soils are often found on drumlins, ridges, and till plains with slopes 0 to 60 percent. Wurtsboro and Swartswood gravelly loams are found on till plains and hills at 300 to $550 \mathrm{~m}$. Wurtsboro soils are present on slopes from 0 to 3 percent, and Swartswood soils are present on slopes from 3 to 8 percent; both soils exhibit low available water capacity. Hollis soils are often excessively drained, very shallow, and formed in a thin mantle of till. Erie stony soils occur on 3 to 8 percent slopes of till plains, hills, and drumlinoid ridges. Erie stony soils are relatively poorly drained and exhibit low available water capacity.

Moist soils include Natchaug, Wawayanda, and Copalisrock soils. Natchaug and Wawayanda soils are very deep, very poorly drained, and occur on slopes 0 to 2 percent. Natchaug soils are common on depressions, till plains, moraines, and flood plains. Wawayanda soils are often in bogs and old lake plains. Copalisrock soils are histic humaquepts, moderately deep, very poorly drained, and occur on 0 to 3 percent slopes at 30 to $150 \mathrm{~m}$ (Olsson, 1981; Bonnell, 1990; Natural Resources Conservation Service and National Park Service, 2013).

\section{Community Type Descriptions}

Although the NYNHP identified nearly a dozen forest communities in the lower Hudson Valley, only the four most prominent in our study sites are discussed in depth in this report; these are Appalachian oak-hickory forest (AOHF), chestnut oak forest (COF), hemlock-northern hardwood forest (HNHF), and oak-tulip tree forest (OTTF; fig. 4B). Many south-facing upper slopes are dominated by northern red oak, and northern slopes are often dominated by eastern hemlock (Tsuga canadensis). Several oaks, hickories (Carya spp.), and pines (Pinus spp.) are found on hilltops and ridges. Where shallow soils are present, vegetation is often open and dominated by shrubs and graminoids (Barringer and Clemants, 2003). Existing forest communities in Harriman and Bear Mountain State Parks are predominantly COFs, but large stands of OTTF and HNHF and small stands of AOHF are present (table 1). The AOHF community is most common at Sterling Forest State Park. Sterling Forest State Park also contains large areas of COF and HNHF, and Black Rock Forest contains large areas of COF and OTTF. The West Point Military Reservation is predominantly AOHF with many large areas of COF and sporadic areas of HNHF and OTTF (Evans and Krahling, 2004; New York Natural Heritage Program, 2018). Several regional threats to these community types exist, in addition to white-tailed deer browsing, 
A. Aggregated soil type

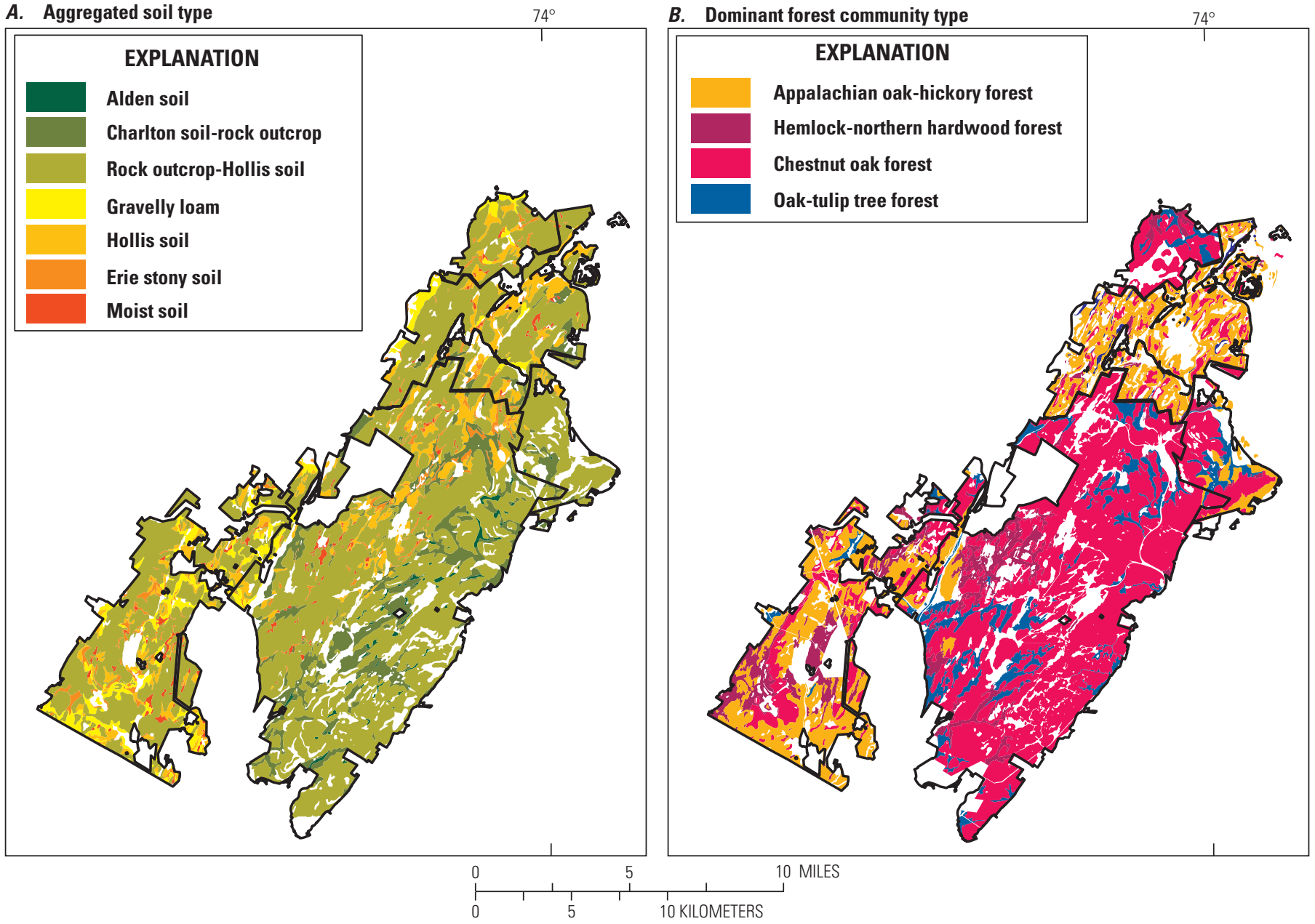

Figure 4. $A$, aggregated soil types and $B$, dominant forest community types present at Harriman, Bear Mountain, and Sterling Forest State Parks, Black Rock Forest, and West Point Military Reservation in New York. Soil type data are from Natural Resources Conservation Service (2018); forest community data are from New York Natural Heritage Program (2018).

Table 1. Forest communities present in selected areas surveyed in the lower Hudson Valley, New York, in 2018.

[Spatial limits of existing forest communities were delineated by the New York Natural Heritage Program (2018). ha, hectare]

\begin{tabular}{|c|c|c|c|c|c|c|}
\hline \multirow[b]{2}{*}{ Study area } & \multirow{2}{*}{$\begin{array}{c}\text { Total area } \\
\text { (ha) }\end{array}$} & \multicolumn{5}{|c|}{ Percentage area of forest community type } \\
\hline & & $\begin{array}{l}\text { Appalachian } \\
\text { oak-hickory }\end{array}$ & Chestnut oak & $\begin{array}{l}\text { Hemlock-northern } \\
\text { hardwood }\end{array}$ & $\begin{array}{l}\text { Oak-tulip } \\
\text { tree }\end{array}$ & Other \\
\hline Harriman State Park & 19,266 & 2 & 65 & 7 & 10 & 17 \\
\hline Bear Mountain State Park & 2,156 & 20 & 41 & 2 & 13 & 24 \\
\hline Sterling Forest State Park & 7,751 & 42 & 18 & 18 & 2 & 20 \\
\hline Black Rock Forest & 1,574 & 0 & 61 & 8 & 13 & 18 \\
\hline West Point Military Reservation & 5,551 & 54 & 14 & 3 & 3 & 27 \\
\hline
\end{tabular}


including increased development, fire suppression, invasive or nonnative pests like gypsy moth (Lymantria dispar) and hemlock woolly adelgid (Adelges tsugae), and recreational overuse (Largay and Sneddon, 2007; Edinger and others, 2014).

\section{Appalachian Oak-Hickory Forest}

The AOHF community type is globally common, though the number and acreage in New York State have declined during the past century due to logging, agriculture, and development. AOHFs are broadly defined and encompass many variants. Most are found on well-drained sites at ridgetops, along upper slopes, and on south- and west-facing slopes (Edinger and others, 2014). Generally, oak-hickory communities likely gradually invaded abandoned pastures, evidenced by open canopies, less distinct vertical stratification, and diverse herb layers of grasses and sedges (Glitzenstein and others, 1990). Common AOHF canopy tree species include white oak, black oak $(Q$. velutina $)$, and pignut hickory $(C$. glabra $)$. Other common tree species include northern red oak, red maple, sugar maple (A. saccharum), shagbark hickory (C. ovata), white ash (Fraxinus americana), and hophornbeam (Ostrya virginiana). Common small trees and shrubs found in oak-hickory forests include flowering dogwood (Cornus florida), American witchhazel (Hamamelis virginiana), lowbush blueberries (Vaccinium angustifolium, Vaccinium pallidum), and mapleleaf viburnum (Viburnum acerifolium). Pennsylvania sedge and several herbs, including wild sarsaparilla (Aralia nudicaulis), false Solomon's seal (Maianthemum racemosum), and roundlobe hepatica (Hepatica nobilis), are common (Edinger and others, 2014).

\section{Chestnut Oak Forest}

The COF community type is globally secure. COFs have declined in number and acreage in New York during the past several decades due to fire suppression and development, although the community is considered secure in New York. COFs are common on well-drained, rocky sites (Edinger and others, 2014) that exhibit distinct vertical stratification consistent with intensive cutting in the early 1900s (Glitzenstein and others, 1990). Chestnut oak increased in relevance in this community as it replaced American chestnut in the early 1900s. Chestnut oak, northern red oak, white oak, and black oak exceed 25 percent of the canopy cover, although chestnut oak and northern red oak typically dominate. Red maple, sweet birch, and remnant chestnut are common associates. The understory is often densely populated with mountain laurel (Kalmia latifolia; 60 to 90 percent cover). In addition, black huckleberry (Gaylussacia baccata), blueberry (Vaccinium spp.), wintergreen (Gaultheria procumbens), wavy hair grass (Deschampsia flexuosa), Virginia creeper (Parthenocissus quinquefolia), Pennsylvania sedge, wild sarsaparilla, and pincushion moss (Leucobryum glaucum) are also common (Edinger and others, 2014).

\section{Hemlock-Northern Hardwood Forest}

The HNHF community type is globally secure, and several large, high-quality, old-growth stands remain intact in New York State. HNHFs declined in number and acreage in recent decades due to logging, agriculture, development, and infestation of the hemlock woolly adelgid, a nonnative insect that preys on hemlock trees. Stands of HNHFs occur in midelevations along slopes and on moist, well-drained swamp margins. Eastern hemlock co-dominates with sugar maple, red maple, sweet birch, northern red oak, American beech, black cherry (Prunus serotina), eastern white pine (P. strobus), yellow birch (B. alleghaniensis), and basswood (Tilia americana) in the canopy layer, though relative cover of eastern hemlock varies from 20 to nearly 100 percent. Striped maple (A. pensylvanicum) is common in the midunderstory. Shrubs include great laurel (Rhododendron maximum) and mapleleaf viburnum. Evergreen woodfern (Dryopteris intermedia), Canada mayflower (Maianthemum canadense), Indian cucumber-root (Medeola virginiana), Christmas fern (Polystichum acrostichoides), and northern starflower (Trientalis borealis) are often present in the ground layer (Edinger and others, 2014).

\section{Oak-Tulip Tree Forest}

The OTTF community type is globally secure but vulnerable in New York State due to development pressure and fragmentation. In the lower Hudson Valley, OTTFs are limited to moist, well-drained sites. The canopy layers of OTTFs are dominated by white oak, chestnut oak, northern red oak, black oak, American beech, and tulip tree. Other canopy trees include red maple, sugar maple, sweet birch, and American basswood. The shrub layer typically contains flowering dogwood, American witchhazel, sassafras, lowbush blueberries, spicebush (Lindera benzoin), and Allegheny blackberry (Rubus allegheniensis). White wood-aster (Eurybia divaricata), false Solomon's seal, common Solomon's seal (Polygonatum biflorum), and New York fern (Thelypteris noveboracensis) are common herbs. Japanese stiltgrass often becomes invasive in oak-tulip tree forests. Compared with the other communities surveyed in this study, OTTFs have the sparsest herb and shrub layers due to their very dense canopies (Edinger and others, 2014).

\section{Methods}

\section{Case-Control Study Design}

We conducted a matched case-control study to understand the putative effects of deer harvest on forest recovery from the biotic effects of chronic herbivory. Case-control studies determine the relative importance of a predictor variable in relation to the presence or absence of the outcome of interest (Mann, 2003). Case-control study designs are well-suited 
to conditions with long latency and rare outcomes (Carlson and Morrison, 2009) and can be applied to shorter time scales than other observational study design options (Pearce, 2016). However, case-control studies are susceptible to selection bias when cases and controls are poorly matched (Rose and van der Laan, 2009).

Accurate matching of case sites with control sites increases the statistical power of the analysis (Mann, 2003) and removes the effects of confounding variables if they are unrelated to the exposure (Pearce, 2016). A confounding source of variation is independently associated with both the indicator variable and the outcome. Although many forest plants tolerate wide variation in growing conditions, their abundance, stature, and productivity vary according to the deviation from optimal levels of sunlight, moisture, and nutrition to which each species is adapted. Consequently, soil type, elevation, topographic position and its derivatives (for example, slope, aspect and moisture availability), and canopy cover confound comparisons of attributes from the same species at different sites (McIntosh, 1962; Day and others, 1988; Russell and Schuyler, 1988; Glitzenstein and others, 1990; Rooney and Dress, 1997; Barringer and Clemants, 2003; Jelaska and others, 2006; Ward and others, 2013). Other important confounders include land cover as it relates to land use history and forest disturbance (Russell, 1980). Therefore, cases were selected randomly, and controls were individually matched to each case (ratio:1:3) along several important environmental gradients. We compared forest attributes measured at sites where deer harvest is permitted (the case sites) and sites where deer harvest is prohibited (the control sites) to identify potential recovery indicators. To obtain a desired statistical power of at least 80 percent, we estimated a minimum allocation of 200 plots for our field surveys, of which 50 were case sites and 150 were control sites (Ejigou, 1996).

We obtained site boundaries for State parks from the New York State GIS Clearinghouse (2018); boundaries for Black Rock Forest and hunting areas at the West Point Military Reservation were obtained from their respective site managers. We obtained a 10-m digital elevation model (DEM; U.S. Geological Survey, 2019), land cover (Homer and others, 2015), tree canopy (Homer and others, 2015), soil type (Natural Resources Conservation Service, 2017), and vegetation community data (Evans and Krahling, 2004; New York Natural Heritage Program, 2018) for the region. We used ArcGIS tools to calculate the slope and aspect parameters from the $10-\mathrm{m}$ DEM. Using metadata obtained for soil type, we aggregated soil types between Orange and Rockland Counties into seven broad soil categories: Alden soils, sandy loams, rock outcrop complexes, Hollis soils, rock outcrop-Hollis complex, Erie stony soils, and other moist soils. From a National Land Cover Database (NLCD; Homer and others, 2015) raster containing only forested areas, all areas with slopes $>50$ percent were removed to avoid treacherous hiking conditions while navigating to plots. We used the ArcGIS Create Random Points tool with a minimum allowed distance of $100 \mathrm{~m}$ to create 150 random points among case sites and 350 random points among control sites. We did not allow for plot placement in the areas of Harriman State Park that permit hunting. We retained plot locations whose NLCD description included evergreen forest, deciduous forest, or mixed forest. We used the matchit() function (Ho and others, 2011) in R (version 3.2.0; The R Foundation, 2015) to match each remaining case plot with at least three control plots based on land cover type, canopy cover percentage, soil type, elevation, slope, and aspect.

\section{Field Survey Protocols}

We navigated to plots in the field using a handheld Global Positioning System (GPS) device. If accessible, we surveyed the plot as it was defined in ArcGIS. For inaccessible plots, we recorded a new set of coordinates in situ as close to the original plot location as possible (typically within 30 to $50 \mathrm{~m}$ ) and within the same forest community type. Plots were deemed inaccessible if they were on treacherous terrain, including rocky cliffs or inundated wetlands; on or near private property; on or near inhabited recreation camps; or near any other hazard deemed unacceptable by the field crew. At each plot, we placed a pin flag in the ground at plot-center and recorded the date, time, and general weather conditions. We attached a fish-eye lens to a smartphone (for example, Motorola Droid Turbo 2 or Google Pixel 2 XL), balanced the phone atop a meter stick placed at plot-center, and took a hemispherical photograph of the forest canopy (fig. 5). We marked a

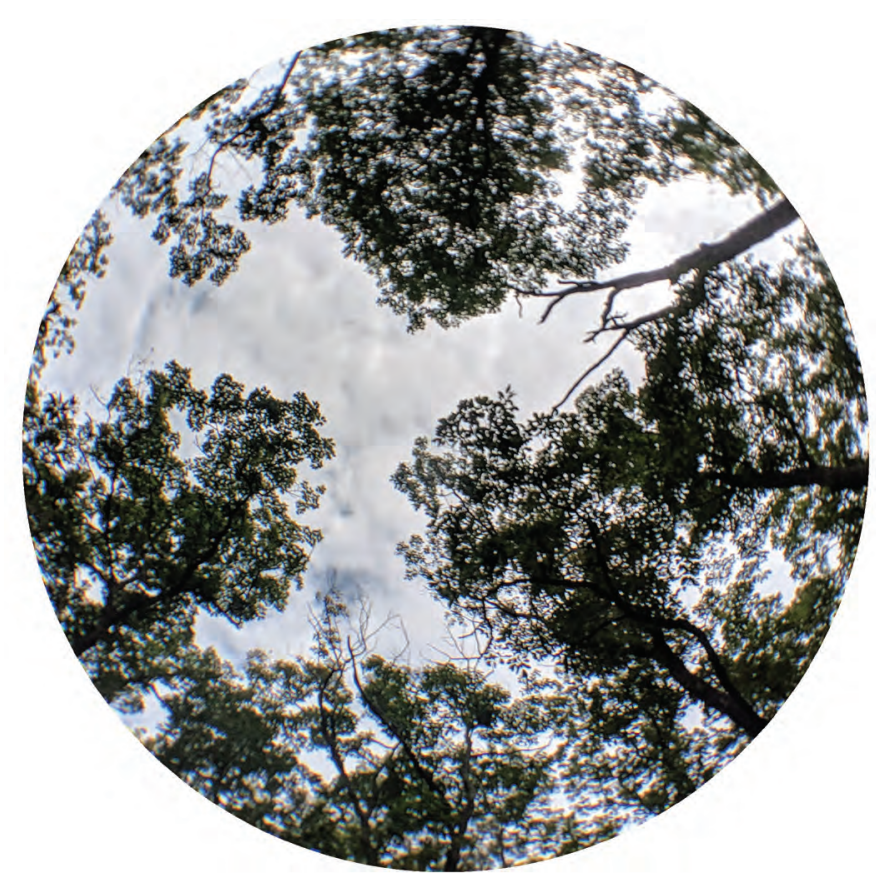

Figure 5. Canopy cover at a control plot in Harriman State Park, New York, photograph captured in 2018 with a smartphone and fish-eye lens. Photograph by Rachel Guerrieri, State University of New York College of Environmental Science and Forestry. 
10- $\mathrm{m}$ boundary in each cardinal direction from plot-center to define the corners of four quadrants. We recorded the species, diameter at breast height (dbh; $1.4 \mathrm{~m}$ high), and distance from plot-center of the nearest tree (that is, $\geq 10.16$-centimeter [cm] dbh) in each quadrant using the point-centered quarter method (PCQM; Cottam and Curtis, 1956; Beasom and Haucke, 1975).

To assess the density of understory trees (species that never accede to the canopy, including flowering dogwood, American witchhazel, and Canadian serviceberry [Amelanchier canadensis]) and saplings (regenerants of canopy constituents) at each plot, we either conducted PCQM on the nearest saplings or small trees ( $>1$-m height, $<10.16-\mathrm{cm} \mathrm{dbh})$ in each quadrant (Cottam and Curtis, 1956) or recorded dbh of all species in each quadrant. Zero density was recorded for plots where all four quadrants (400-square meter $\left[\mathrm{m}^{2}\right]$-area) had no saplings or small trees; otherwise, density was prorated per hectare. We measured clump density for tall shrubs ( $>1$-m height, usually multistemmed), including American witchhazel, mountain laurel, serviceberry (Amelanchier spp.), and highbush blueberry (Vaccinium corymbosum). To assess percent ground cover, we used a smartphone application to generate two random numbers between 1 and 10, together forming a coordinate from plot-center where we placed a $1-\mathrm{m}^{2}$ quadrat on the ground, oriented parallel with plot-center markers. Using ocular estimation, we recorded the percentage cover (areal projection of all above-ground parts $\leq 1$-m tall onto a two-dimensional plane; Elzinga and others, 1998) of rock, bare soil, and all plant species present, including tree seedlings and small shrubs $(\leq 1-\mathrm{m}$ height). Ground cover was assessed at two random subplots within each quadrant for a total of eight placements at each plot. Lastly, we recorded any plant species encountered but not captured in the sampling protocol (table 2).

If an unidentifiable plant was encountered during surveys, several photographs were taken with a Canon T5i digital single-lens reflex camera with an 18- to 55-millimeter (mm) zoom lens. For each unidentifiable plant, we recorded photograph numbers, detailed notes about the plant and its environment, and any visible flowers or fruits. In rare instances, we collected and pressed a specimen. We identified "unknown" plants and specimens to the lowest taxonomic level possible (Natural Resources Conservation Service, 2018; Weldy and others, 2018) and consulted subject area experts for assistance with graminoids (A. Petzke and M. Hough, State University of New York College of Environmental Science and Forestry, oral commun., 2018).

To assess the age of trees last recruited in the canopy, we located a sample of the smallest-diameter subcanopy trees $(\mathrm{dbh}>10.16 \mathrm{~cm})$ in Harriman State Park of several species common in the forest canopy (such as, red maple, sugar maple, sweet birch, pignut hickory, white oak, chestnut oak, northern red oak, and eastern hemlock) at least $50 \mathrm{~m}$ from the nearest roadway. For each tree, we used an increment borer to collect a core sample. We knelt to approximately $0.6 \mathrm{~m}$ above the ground, positioned the borer in the center of the tree, and inserted the borer perpendicular to the trunk. We carefully extracted the core, placed it in a plastic straw for transportation, and labeled it with the tree number and species. Cores were mounted and then cut and sanded with progressively

Table 2. Forest vegetation layer attributes to be calculated from field data collected among control and case sites in the lower Hudson Valley, New York, in 2018.

[Control sites are Harriman and Bear Mountain State Parks, and case sites are Sterling Forest State Park, Black Rock Forest, and West Point Military Reservation. no./ha, number per hectare; $\mathrm{m}^{2} /$ ha, square meter per hectare; $\%$, percent]

\begin{tabular}{|c|c|c|c|c|c|}
\hline Layer & Constituent & Attribute & Unit & Justification & Source \\
\hline Canopy & Trees & $\begin{array}{l}\text { Density } \\
\text { Basal area }\end{array}$ & $\begin{array}{l}\text { no./ha } \\
\mathrm{m}^{2} / \mathrm{ha}\end{array}$ & $\begin{array}{l}\text { Tree density and basal area indicate the degree of } \\
\text { crowding; fully stocked forests have little room } \\
\text { for new trees without management }\end{array}$ & $\begin{array}{l}\text { Behrend and others, } \\
\text { 1970; Healy 1997; } \\
\text { Sage and others, } 2003\end{array}$ \\
\hline Subcanopy & $\begin{array}{l}\text { Small trees } \\
\text { Saplings } \\
\text { Tall shrubs }\end{array}$ & Density & no./ha & $\begin{array}{l}\text { Density of small trees, saplings, and tall shrubs } \\
\text { may indicate a past release from deer herbivory }\end{array}$ & $\begin{array}{l}\text { Healy 1997; Holm and } \\
\text { others, } 2013\end{array}$ \\
\hline
\end{tabular}

${ }^{*}$ Pennsylvania sedge and hay-scented fern become interfering vegetation after chronic deer herbivory. 
finer sand paper and steel wool as needed, then examined under a dissecting scope at high magnification to distinguish annual rings and determine tree age. We estimated conservative ages because rings of annual growth were often indistinct, many cores did not go through the center of the tree, and cores were not extracted at ground level.

\section{Calculations}

We calculated basal area, relative density, relative frequency, relative dominance, and importance values for each species among plots for large trees $(\geq 10.16$-cm dbh) and small trees $(<10.16-\mathrm{cm} \mathrm{dbh})$ between site designations (case or control sites). We used the following equation to calculate importance value $(I V)$ for each species:

$$
I V=R D+R D m+R F
$$

where

$\begin{aligned} R D & \text { is relative density, } \\ R D m & \text { is relative dominance, and } \\ R F & \text { is relative frequency. }\end{aligned}$

Importance values were used to rank the most important species recorded during field surveys. We calculated species richness, Shannon's diversity index, and Shannon's evenness index (Shannon and Weaver, 1949; DeJong, 1975) for large trees and small trees and saplings between case and control plots. Following Chapman and McEwan (2016), we transformed slope, aspect, and elevation to range between 0 and 2 , with lower values corresponding to more xeric conditions (south-facing slopes, higher elevations, and areas with greater steepness), and calculated a modified Parker's topographic relative moisture index $(M I)$ :

$$
M I=\frac{E+A+(S \times 0.05)}{5} \times 100,
$$

where

$$
\begin{aligned}
E & \text { is elevation, } \\
A & \text { is aspect, and } \\
S & \text { is slope. }
\end{aligned}
$$

Canopy images were enlarged and cropped in Adobe Photoshop CS6 to standardize size and canopy radius. Cropped images were then imported into the Gap Light Analyzer software (GLA; Frazer and others, 1999). Each image was first registered, during which the initial azimuth $\left(0^{\circ} \mathrm{N}\right)$ and opposing azimuth $\left(180^{\circ} \mathrm{S}\right)$ were identified to establish the geographic orientation and circular extent of the image. Because the images were the same size, the initial and opposing azimuths were the same for all images. We changed the configuration settings by adjusting the XY coordinates for each plot. We then applied a blue color plane to assist in separating the canopy from the open sky by minimizing light scattering from clear or cloudy skies. For most images, a threshold of 128 was applied to further separate the sky from canopy. For images with a lens flare, the threshold was adjusted to 150 to reduce focus on the problem area and directly analyze only true canopy gaps. We used the Calculate function in GLA to generate canopy openness and light transmission values.

\section{Statistical Analysis}

In preparation for statistical analysis, we transformed the azimuth of the aspect to its linear form (Roberts and Cooper, 1989). We logarithmically $\left(\log _{10}\right)$-transformed all densities and basal area measurements (tree density, tree basal area, tall shrub clump density, small tree density, and sapling density) to reduce skewness and stabilize the variance. We added the value of 1 to all quantities to account for real zeroes in the data. For slope, moisture index, canopy openness, and all ground cover percentages and proportions, we used the angular transformation (Ahrens and others, 1990; Sokal and Rohlf, 1995). We screened matching variables (elevation, slope, aspect, and canopy openness) for differences between case and control sites to verify that the matching process worked. We similarly screened nonmatching variables (moisture index, tree basal area, and densities of trees, tall shrub clumps, small trees, and saplings) used to characterize the canopy and subcanopy layers between case and control sites. We used the general linear model PROC GLM (SAS Institute Inc., 2017) to perform a one-way analysis of variance for unbalanced sample sizes. We submitted each variable to standard diagnostic tests to ensure approximate normality of residuals, and tested for homogeneity of within-group variances using the HOVTEST $=\mathrm{BF}$ option. For variables that did not meet basic assumptions, we conducted an equivalent, nonparametric test (Kruskal-Wallis test on Wilcoxon scores) using PROC NPAR1WAY.

We used the conditional logistic regression PROC LOGISTIC (SAS Institute Inc., 2017) to analyze the matched case-control data (Hosmer and Lemeshow, 2000) and determined the significance of each indicator variable using standard Wald $\chi^{2}$ tests. For significant variables, we estimated the odds ratio, a measure of association between an indicator variable and outcome. Odds ratios are used to compare relative odds of the occurrence of the outcome (for example, recovery from herbivory), given the variable of interest (for example, forest attributes; Szumilas, 2010). An odds ratio significantly $>1$ indicates a positive association between the variable and outcome, whereas an odds ratio significantly $<1$ indicates a negative association. We adopted the conventional $\mathrm{p}$-value $\leq 0.05$ as indicating statistical significance for all tests performed in this report. 


\section{Results}

We surveyed 204 vegetation plots among the five sites, 153 of which were on control sites and 51 were on case sites (fig. 6; table 3). Plots were located on aspects in all four cardinal directions and slopes from 0 to 51 percent (fig. 7). Across all plots, we recorded 37 tree species, 22 shrub species, 57 herbaceous species, and 19 species of graminoids. Of 263 individual unknowns encountered in the field, we identified 92.4 percent of them upon further review. We observed six species in the family Ericaceae, each of which contributes to the desired forest condition of healthy oak forests: highbush blueberry, lowbush blueberry, mountain laurel, spotted wintergreen (Chimaphila maculata), wintergreen, and black huckleberry. We observed 13 nonnative plants among plots: Sweet vernalgrass (Anthoxanthum odoratum), Japanese barberry, oriental bittersweet (Celastrus orbiculatus), Japanese stiltgrass, and multiflora rose (Rosa multiflora) were found in many sites. Japanese barberry was observed on all control plots and case plots in AOHF and COF. Japanese stiltgrass was observed in all forest types except OTTF on case sites. Sweet vernalgrass was observed on all control plots except AOHF and was not observed on case plots. Several additional nonnative species were present in $<1$ percent of plots surveyed, including tree of heaven (Ailanthus altissima), bladder senna (Colutea arborescens), bindweed (Convolvulus spp.), pinks (Dianthus spp.), broad-leaved helleborine (Epipactis helleborine), burning bush (Euonymus alatus), wineberry (Rubus phoenicolasius), and stonecrops (Sedum spp.). Burning bush, a genus highly preferred by deer (Webster and others, 2005b), was observed on many case plots, but was never observed on control plots. Several unknown species were not identified due to diminutive size or lack of flowering or fruiting bodies, though our categorization of plants for analysis (for example, graminoids, herbs) made further distinction unnecessary.

In AOHF communities, we observed 14 canopy tree species among control plots and 10 tree species among case plots (app. 1). On control and case plots, canopies in AOHF were dominated by red maple, sugar maple, sweet birch, and northern red oak. Control plots occasionally had sugar maple saplings, but no other species of saplings were present. Saplings of sugar maple, sweet birch, pignut hickory, American beech, American witchhazel, and hophornbeam were common on case plots. Ground cover on case plots was predominantly Pennsylvania sedge, hay-scented fern, black huckleberry, Virginia creeper, highbush blueberry, lowbush blueberry, and mapleleaf viburnum. Ground cover on control plots was composed of Pennsylvania sedge, highbush blueberry, and black huckleberry and the nonnative plant species Japanese barberry and Japanese stiltgrass. Seventeen seedling species were observed on case plots, most frequently red maple, sugar maple, chestnut oak, northern red oak, and American hornbeam (Carpinus caroliniana). Twelve seedling species were observed on control plots, though most were red maple, American beech, American basswood, and tulip tree.
In COF communities, we observed 22 canopy tree species among control plots and 21 tree species among case plots. On control and case plots, canopies in COF on were dominated by red maple, sugar maple, chestnut oak, and northern red oak. Control plots occasionally had sugar maple saplings. Saplings of chestnut oak, northern red oak, red maple, Canada serviceberry, sweet birch, pignut hickory, and American witchhazel were common on case plots. Ground cover on case and control plots was predominantly Pennsylvania sedge, black huckleberry, mountain laurel, lowbush blueberry, and highbush blueberry. Additional native ground cover on case plots included hay-scented fern, Canada mayflower, Virginia creeper, mapleleaf viburnum, and poison ivy (Toxicodendron radicans). Nineteen tree species were observed as seedlings among all plots, with 14 species observed on both cases and controls. Striped maple (Acer pensylvanicum), flowering dogwood, red pine (Pinus resinosa), and American elm (Ulmus americana) were only observed among case plots. Yellow birch (Betula alleghaniensis), American hornbeam, shagbark hickory (Carya ovata), bigtooth aspen (Populus grandidentata), and slippery elm (Ulmus rubra) were only observed among control plots. Red maple, sugar maple, chestnut oak, northern red oak, and hophornbeam were most frequent on case plots. Red maple, sugar maple, and American beech were more common on control plots.

In HNHF communities, we observed 12 canopy tree species among control plots and 7 tree species among case plots. On control and case plots, canopies in HNHF were dominated by red maple, chestnut oak, northern red oak, and eastern hemlock. Control plots occasionally had eastern white pine and eastern hemlock saplings. Saplings of striped maple, sugar maple, sweet birch, American hornbeam, blackgum (Nyssa sylvatica), and American witchhazel were present on case plots. Ground cover on case plots included partridgeberry (Mitchella repens), hay-scented fern, spicebush, Canada mayflower, Virginia creeper, poison ivy, lowbush blueberry, and grapes (Vitis spp.). Ground cover on control plots was composed of Pennsylvania sedge, hay-scented fern, mountain laurel, lowbush blueberry, and highbush blueberry. Eleven seedling species were observed on case plots, largely red maple, American beech, American basswood, and northern red oak. Eleven seedling species were observed on control plots, including red maple, sugar maple, yellow birch, American beech, eastern white pine, and eastern hemlock.

In OTTF communities, we observed 15 canopy tree species among control plots and 3 canopy tree species among case plots. On control and case plots, canopies in OTTF were dominated by red maple, sugar maple, sweet birch, chestnut oak, and northern red oak. Control plots often had red maple and sugar maple saplings. Saplings of red maple, striped maple, sweet birch, American hornbeam, pignut hickory, chestnut oak, and American witchhazel were present on case plots. Ground cover on case and control plots included Pennsylvania sedge, lowbush blueberry, highbush blueberry, and black huckleberry. Hay-scented fern was also observed on case plots. Seven seedling species were observed in case plots, 


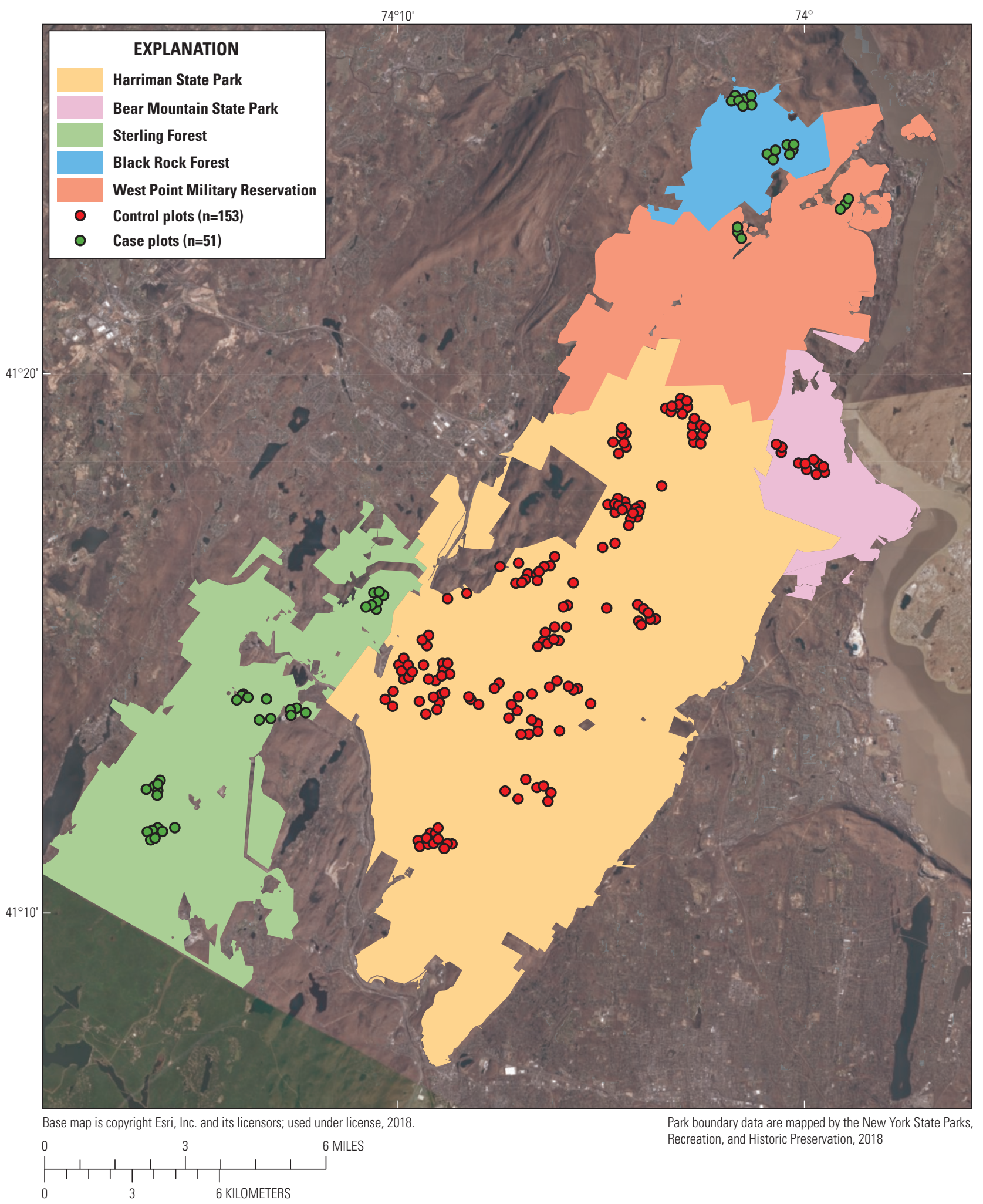

Figure 6. Locations of all plots surveyed among Harriman, Bear Mountain, and Sterling Forest State Parks, Black Rock Forest, and West Point Military Reservation in New York in summer 2018 to assess effects of white-tailed deer herbivory on forest vegetation. Control and case plots are from Kilheffer and others (2019). n, number of plots. 
Table 3. Plots surveyed in common forest community types in the Harriman, Bear Mountain, and Sterling Forest State Parks, Black Rock Forest, and West Point Military Reservation, New York, in 2018.

[Common forest community types are defined by New York Natural Heritage Program (2018). Proportions of control and case plots were calculated for comparison. NYNHP, New York Natural Heritage Program; ID, identifier; n, number of plots; H, Harriman State Park; BM, Bear Mountain State Park; SF, Sterling Forest State Park; BRF, Black Rock Forest; WPMR, West Point Military Reservation; XX, not applicable]

\begin{tabular}{|c|c|c|c|c|c|c|c|c|}
\hline \multirow{2}{*}{$\begin{array}{c}\text { NYNHP } \\
\text { ID }\end{array}$} & \multirow{2}{*}{ Forest community type } & \multicolumn{3}{|c|}{ Control plot (n=153) } & \multicolumn{4}{|c|}{ Case plot $(n=51)$} \\
\hline & & H & BM & Proportion & SF & BRF & WPMR & Proportion \\
\hline 1 & Hemlock-northern hardwood & 14 & 0 & 0.09 & 1 & 1 & 1 & 0.06 \\
\hline 2 & Chestnut oak & 97 & 4 & 0.67 & 20 & 11 & 1 & 0.63 \\
\hline 3 & Appalachian oak-hickory & 9 & 4 & 0.08 & 10 & 0 & 4 & 0.27 \\
\hline 5 & Oak tulip tree & 23 & 2 & 0.16 & 0 & 2 & 0 & 0.04 \\
\hline Total & & 143 & 10 & $\mathrm{XX}$ & 31 & 14 & 6 & $\mathrm{XX}$ \\
\hline
\end{tabular}

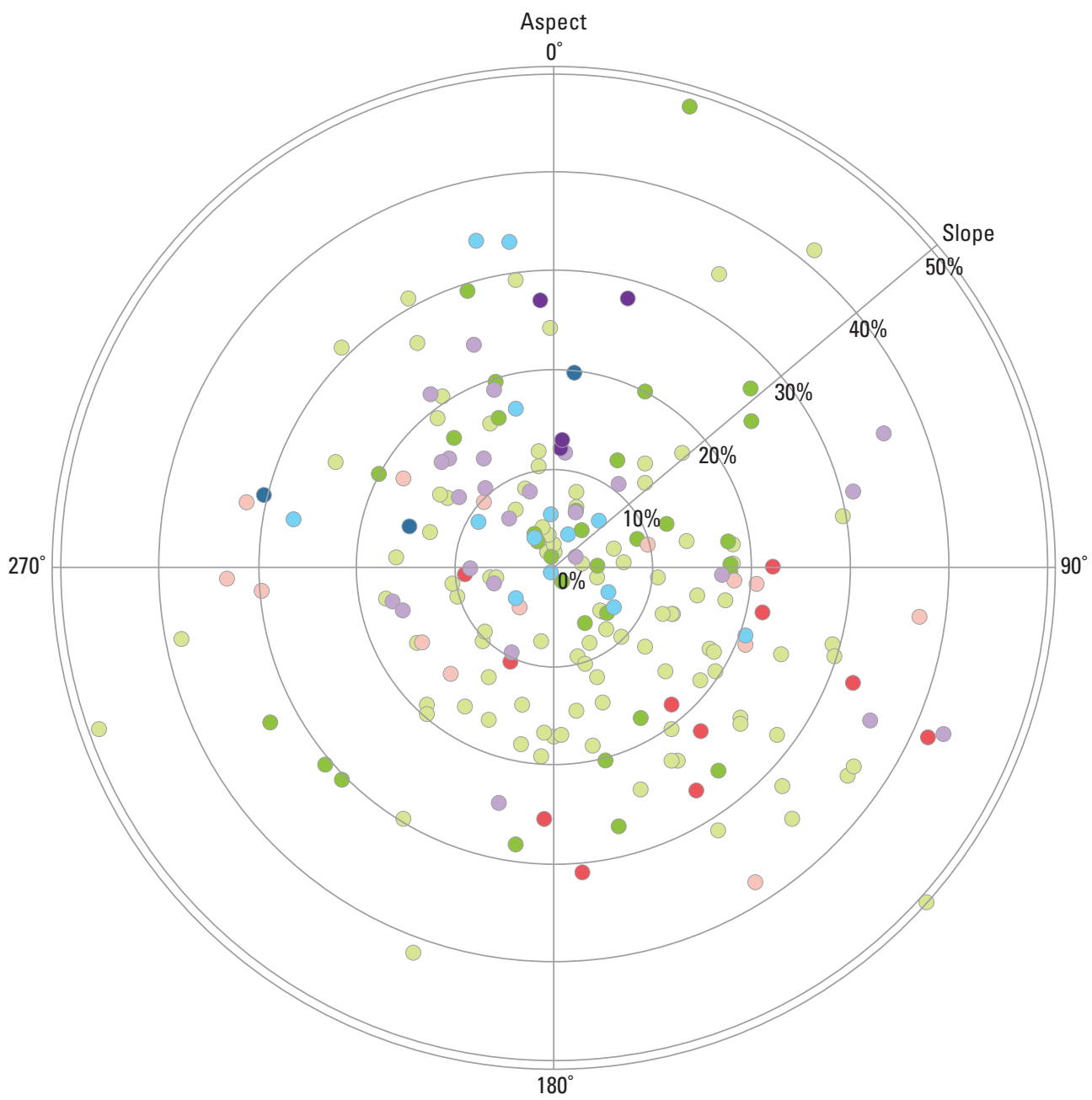

\section{EXPLANATION}

Case plot

- Oak-tuliptree forest

- Hemlock-northern hardwood forest

- Appalachian oak-hickory forest

- Chestnut oak forest

\section{Control plots}

- Oak-tuliptree forest

- Hemlock-northern hardwood forest

- Appalachian oak-hickory forest

- Chestnut oak forest $90^{\circ}$

Figure 7. Slope and aspect of plots surveyed in the lower Hudson Valley, New York, to assess effects of white-tailed deer herbivory on forest vegetation. Slope is measured in percent $(\%)$, and aspect is measured in degrees azimuth $\left({ }^{\circ}\right)$. 
though most were striped maple, red maple, or chestnut oak. Ten seedling species were observed on control plots, but most seedlings were red maple, sugar maple, American beech, or American basswood.

Among forest types, average density of large trees ( $\geq 10.16-\mathrm{cm} \mathrm{dbh}$ ) was 596 trees per hectare among case plots and 415 trees per hectare among control plots (table 4). Average densities of small trees or saplings $(<10.16-\mathrm{cm}$ dbh) and tall shrub clumps were four times greater among case than control plots. In decreasing order of importance, the canopy among case plots was dominated by northern red oak, red maple, sweet birch, sugar maple, and chestnut oak (table 5). Similarly, the canopy among control plots was dominated by northern red oak, sugar maple, chestnut oak, red maple, and white oak. The subcanopy among case plots was dominated by sweet birch, red maple, American witchhazel, hophornbeam, and American beech (table 6). Subcanopies among control plots were dominated by sugar maple, American beech, red maple, sweet birch, and eastern white pine. Eastern white

Table 4. Summary statistics between plots surveyed on case and control sites surveyed in the lower Hudson Valley, New York, in 2018.

[Case sites are Sterling Forest State Park, Black Rock Forest, and West Point Military Reservation, and control sites are Harriman and Bear Mountain State Parks. cm, centimeter; dbh, diameter at breast height; \#/ha, number per hectare; $\mathrm{m}^{2} /$ ha, square meter per hectare]

\begin{tabular}{lcc}
\hline & Case & Control \\
\hline Number of plots surveyed & 51 & 153 \\
Average canopy openness & 24.2 & 26.1 \\
$\quad$ Standard error & 1.0 & 0.7 \\
Average moisture index & 48.3 & 53.4 \\
$\quad$ Standard error & 2.0 & 1.1 \\
Ground cover, number of quadrats & 408 & 1,118 \\
Species richness among plots & 97 & 104 \\
\hline \multicolumn{1}{c}{ Large trees $(\geq 10.16-\mathrm{cm} \mathrm{dbh})$} & \\
\hline Mean tree density (\#/ha) & 596 & 415 \\
Mean tree basal area (m ${ }^{2} /$ ha) & 46 & 39 \\
Species richness among plots & 22 & 26 \\
Shannon's diversity index & 2.3 & 2.4 \\
Shannon's evenness index & 0.7 & 0.7 \\
\hline \multicolumn{1}{c}{ Small trees/saplings $(<10.16-\mathrm{cm} \mathrm{dbh})$} & \\
\hline Mean small tree/sapling density (\#/ha) & 369 & 79 \\
Species richness among plots & 26 & 17 \\
Shannon's diversity index & 2.3 & 1.8 \\
Shannon's evenness index & 0.7 & 0.6 \\
\hline Tall shrub clump density (\#/ha) & 136 & 28 \\
\hline
\end{tabular}

Table 5. Characteristics of trees between case and control sites surveyed in the lower Hudson Valley, New York, in 2018.

[Trees are defined as $\geq 10.16$ centimeters $(\mathrm{cm})$ in diameter at breast height (dbh). Case sites are Sterling Forest State Park, Black Rock Forest, and West Point Military Reservation, and control sites are Harriman and Bear Mountain State Parks. Importance value is calculated from equation 1 of this report. NRO, northern red oak; REM, red maple; SWB, sweet birch; SUM, sugar maple; $\mathrm{CHO}$, chestnut oak]

\begin{tabular}{|c|c|c|c|}
\hline Species & Characteristic & Case & Control \\
\hline \multirow[t]{4}{*}{ NRO } & Rank of importance value & 1 & 1 \\
\hline & Relative density & 23.5 & 21.9 \\
\hline & Relative dominance & 37.8 & 37.5 \\
\hline & Relative frequency & 20.6 & 21.6 \\
\hline \multirow[t]{4}{*}{ REM } & Rank of importance value & 2 & 4 \\
\hline & Relative density & 16.2 & 11.7 \\
\hline & Relative dominance & 8.5 & 4.2 \\
\hline & Relative frequency & 16.2 & 13.4 \\
\hline \multirow[t]{4}{*}{ SWB } & Rank of importance value & 3 & 6 \\
\hline & Relative density & 15.7 & 4.9 \\
\hline & Relative dominance & 9 & 2.9 \\
\hline & Relative frequency & 13.2 & 5.5 \\
\hline \multirow[t]{4}{*}{ SUM } & Rank of importance value & 4 & 2 \\
\hline & Relative density & 13.2 & 20.7 \\
\hline & Relative dominance & 9.6 & 12.7 \\
\hline & Relative frequency & 11.8 & 14.9 \\
\hline \multirow[t]{4}{*}{$\mathrm{CHO}$} & Rank of importance value & 5 & 3 \\
\hline & Relative density & 11.8 & 14 \\
\hline & Relative dominance & 11.8 & 15.5 \\
\hline & Relative frequency & 11 & 13.4 \\
\hline
\end{tabular}

pine was ranked fifth in subcanopy dominance among control plots and 26th among case plots. American beech was ranked fifth in subcanopy dominance among case plots, but second among control plots. Fourteen oak saplings or small trees were observed throughout all surveys, and only two were on control sites. Among sites, ground cover was predominantly small shrubs and tree seedlings (fig. 8) and dense clusters of American beech sprouts were often observed at Harriman State Park (fig. 9). Seedlings on case sites, in decreasing order of coverage, were predominantly red maple, chestnut oak, hophornbeam, and northern red oak. Seedling cover on control sites, in decreasing order of coverage, comprised mostly American beech, red maple, and sugar maple.

One-way analysis of variance verified no significant differences in elevation, slope, aspect, or canopy openness between case and control sites. Case sites were significantly more xeric than control sites. Case sites also exhibited greater tree density (large and small trees), greater tall shrub clump 
Table 6. Characteristics of small trees and saplings between case and control sites surveyed in the lower Hudson Valley, New York, in 2018.

[Small trees are defined as $<10.16$ centimeters $(\mathrm{cm})$ in diameter at breast height (dbh). Case sites are Sterling Forest State Park, Black Rock Forest, and West Point Military Reservation, and control sites are Harriman and Bear Mountain State Parks. Importance value is calculated from equation 1 of this report. SWB, sweet birch; REM, red maple; AMW, American witchhazel; HHB, hophornbeam; AMB, American beech; SUM, sugar maple; EWP, eastern white pine]

\begin{tabular}{|c|c|c|c|}
\hline Species & Characteristic & Case & Control \\
\hline \multirow[t]{4}{*}{ SWB } & Rank of importance value & 1 & 4 \\
\hline & Relative density & 26.9 & 12 \\
\hline & Relative dominance & 22.7 & 12.4 \\
\hline & Relative frequency & 13.5 & 5.6 \\
\hline \multirow[t]{4}{*}{ REM } & Rank of importance value & 2 & 3 \\
\hline & Relative density & 13 & 6.7 \\
\hline & Relative dominance & 22.3 & 12.4 \\
\hline & Relative frequency & 11.2 & 14.5 \\
\hline \multirow[t]{4}{*}{ AMW } & Rank of importance value & 3 & 8 \\
\hline & Relative density & 12.7 & 1.4 \\
\hline & Relative dominance & 12.8 & 1.3 \\
\hline & Relative frequency & 12.9 & 4.8 \\
\hline \multirow[t]{4}{*}{ HНB } & Rank of importance value & 4 & 9 \\
\hline & Relative density & 15.4 & 0.7 \\
\hline & Relative dominance & 7.1 & 1 \\
\hline & Relative frequency & 5.3 & 2.4 \\
\hline \multirow[t]{4}{*}{ AMB } & Rank of importance value & 5 & 2 \\
\hline & Relative density & 7 & 25.9 \\
\hline & Relative dominance & 4.6 & 10.4 \\
\hline & Relative frequency & 6.5 & 8.9 \\
\hline \multirow[t]{4}{*}{ SUM } & Rank of importance value & 6 & 1 \\
\hline & Relative density & 3.2 & 35.2 \\
\hline & Relative dominance & 4.6 & 51.3 \\
\hline & Relative frequency & 6.5 & 40.3 \\
\hline \multirow[t]{4}{*}{ EWP } & Rank of importance value & 26 & 5 \\
\hline & Relative density & 0.1 & 11.8 \\
\hline & Relative dominance & 0 & 1.3 \\
\hline & Relative frequency & 0.6 & 7.3 \\
\hline
\end{tabular}

density, and greater sapling density than control sites. Ground layer vegetation among case sites exhibited greater tree seedling cover, less Pennsylvania sedge cover, and greater herb cover than control sites. Occurrence results mirrored those of percent cover with the addition of small shrubs, which were observed more frequently among case sites.

Despite modest differences in tree density and moisture index, none of the canopy layer variables was a significant prognostic indicator of forest recovery in conditional logistic regressions. However, significant differences in the log-odds between cases and controls emerged in the subcanopy and ground vegetation layers (table 7). The odds of recovery $(\mathrm{OR})$ were nearly three times greater among case sites than control sites on the basis of sapling $(\mathrm{OR}=2.9: 1)$, small tree $(\mathrm{OR}=2.7: 1)$, and tall shrub clump $(\mathrm{OR}=2.1: 1)$ densities. In the ground layer, the odds of recovery were distinguished by greater seedling and herb cover and less Pennsylvania sedge and nonnative plant cover among case sites compared with control sites. In addition, larger proportional occurrences of seedlings, herbs, and small shrubs were associated with case sites than with control sites. The odds ratio for proportional occurrence of native species was $<1$, indicating that control sites were associated with greater representation of native species than case sites.

We cored 25 trees in Harriman State Park (figs. 10 and 11). The average age of all cored trees was at least 108.5 years with a standard error of 3.7 years (table 8 ). The sweet birch core and one red maple core require further investigation for accurate aging because ring widths were narrow and indistinct, even under the highest magnifications. The remaining red maple cores indicated ages of at least 96 and 60 years. The two northern red oak cores indicated ages of at least 100 and 104 years. The sugar maple core indicated an age of at least 120 years, and the white oak core indicated an ago of at least 104 years. Chestnut oak cores indicated, on average, an age of at least 111 years. The average minimum age of eastern hemlock on the basis of cores was 116 years old (dbh range: 9.4 to $25.2 \mathrm{~cm}$ ). Pignut hickory cores indicated ages of at least 83 and 94 years (dbh range: 11.4 to $14.5 \mathrm{~cm}$ ). 
A. Percent ground cover of vegetation categories between case and control sites

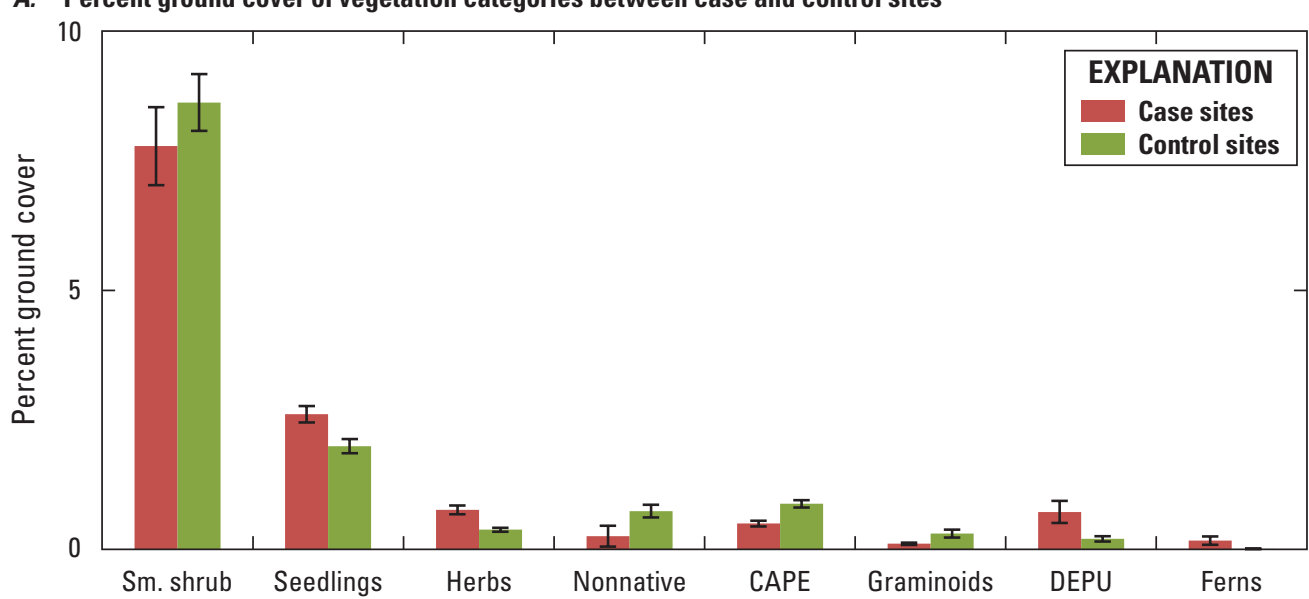

B. Proportion of plot occurrence of vegetation categories for case and control sites

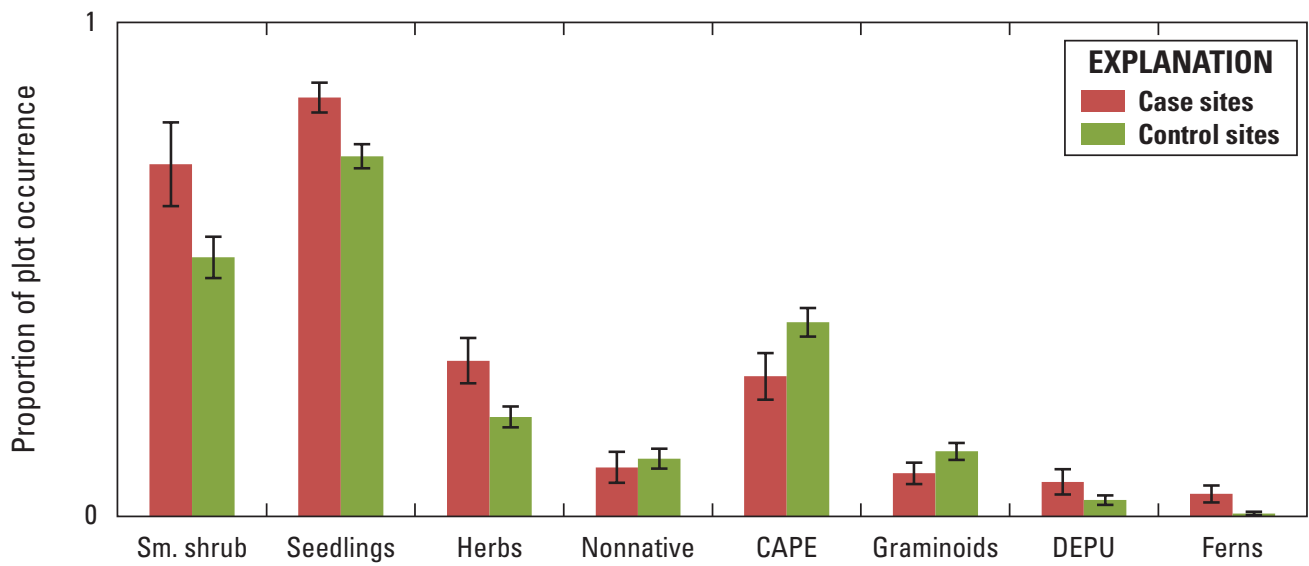

Figure 8. Mean and standard error of $A$, percent ground cover and $B$, proportion of plots containing each ground cover category between case and control sites surveyed in the lower Hudson Valley, New York, in 2018. Case sites are Sterling Forest State Park, Black Rock Forest, and West Point Military Reservation, and control sites are Harriman and Bear Mountain State Parks. Pennsylvania sedge (Carex pensylvanica; CAPE) and hay-scented fern (Dennstaedtia punctilobula; DEPU) become interfering vegetation after chronic deer herbivory. Graminoids exclude Pennsylvania sedge, and ferns exclude hay-scented fern. Sm. shrub = small shrubs ( $\leq 1$ meter in height). 


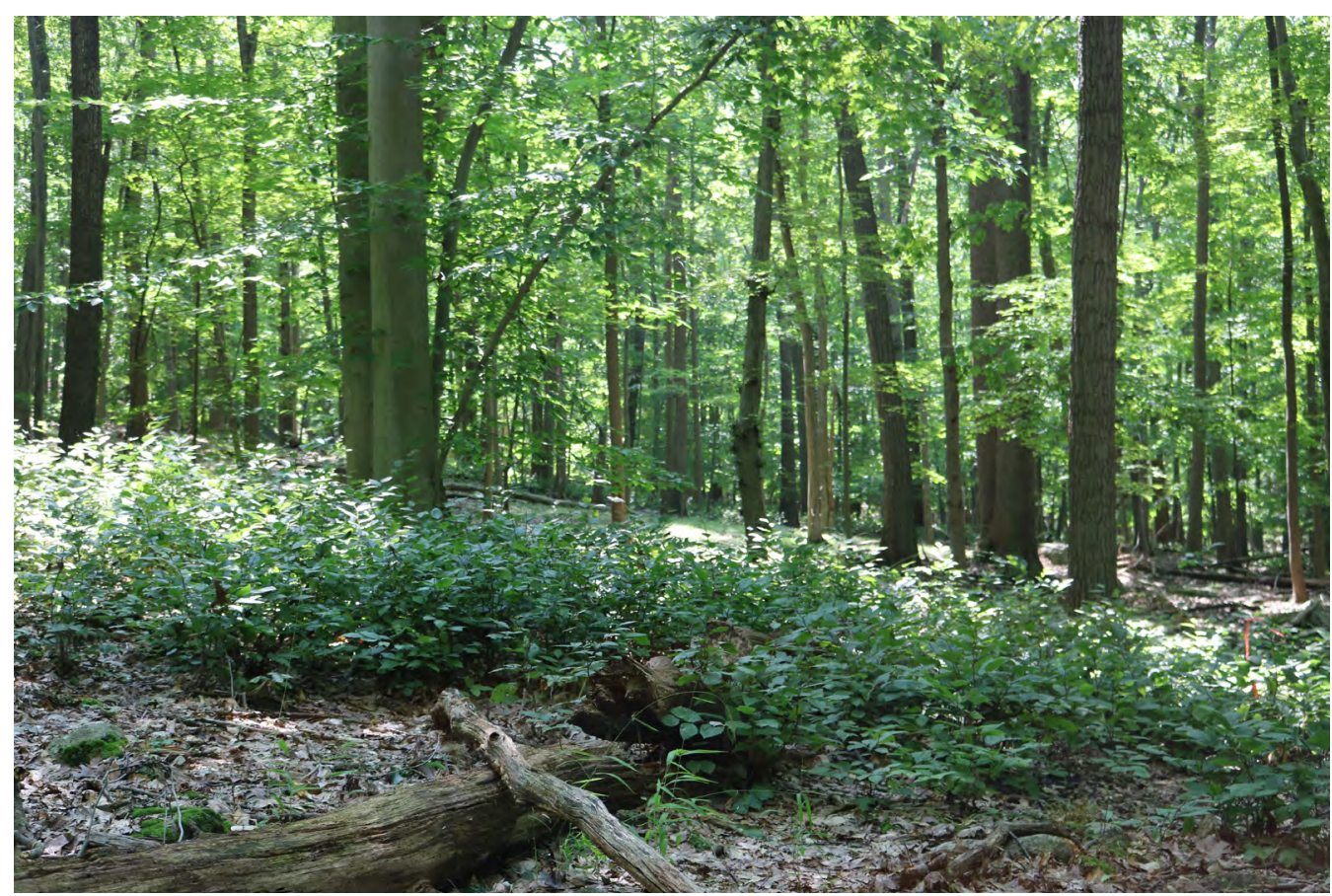

Figure 9. A dense cluster of American beech (Fagus grandifolia) sprouts observed in Harriman State Park, New York, on August 10, 2018. Photograph by Chellby Kilheffer, State University of New York College of Environmental Science and Forestry.

Table 7. Significant odds ratios from case-control conditional logistic regression for ground layer vegetation cover and occurrence surveyed among sites in the lower Hudson Valley, New York, in 2018.

[Odds are considered to be significant when $\mathrm{p} \leq 0.05$. Dashes signify that the odds ratio was not significant and therefore not reported.]

\begin{tabular}{lcc}
\hline \multirow{2}{*}{\multicolumn{1}{c}{ Variable }} & \multicolumn{2}{c}{ Case control } \\
\cline { 2 - 3 } & Cover & Occurrence \\
\hline Seedlings & $13.7: 1$ & $4.9: 1$ \\
Small shrubs & - & $2.9: 1$ \\
Herbs & $>999: 1$ & $2.1: 1$ \\
Pennsylvania sedge & $0.006: 1$ & $0.5: 1$ \\
Nonnative species & $0.006: 1$ & - \\
Native species & - & $0.1: 1$ \\
\hline
\end{tabular}



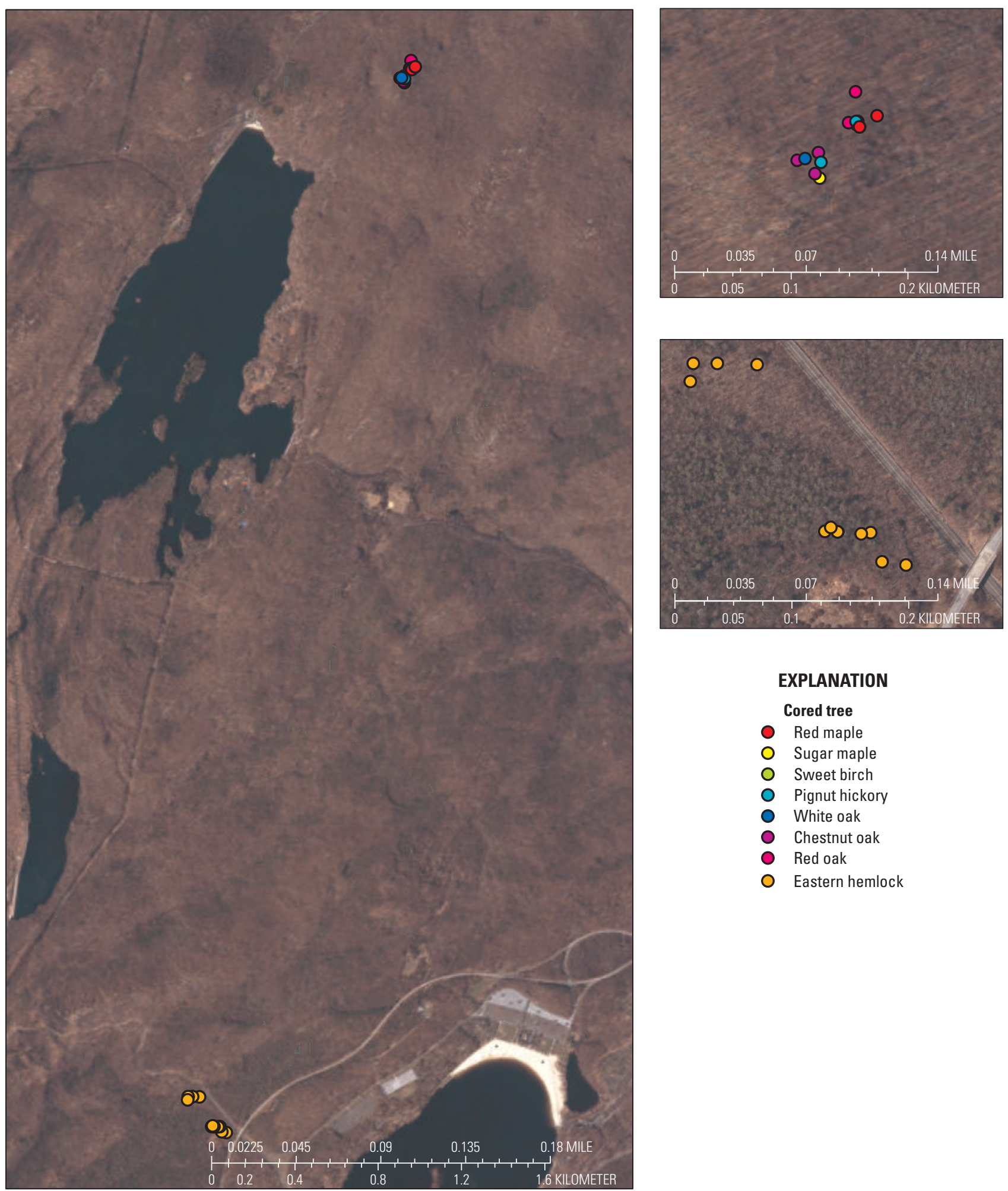

\section{EXPLANATION}

Cored tree

O Red maple

O Sugar maple

O Sweet birch

O Pignut hickory

○ White oak

O Chestnut oak

- Red oak

Eastern hemlock

Base map is copyright Esri, Inc. and its licensors; used under license, 2018.

Figure 10. Locations of trees cored at Harriman State Park, New York, in 2018 to assess the amount of time since last canopy recruitment. 


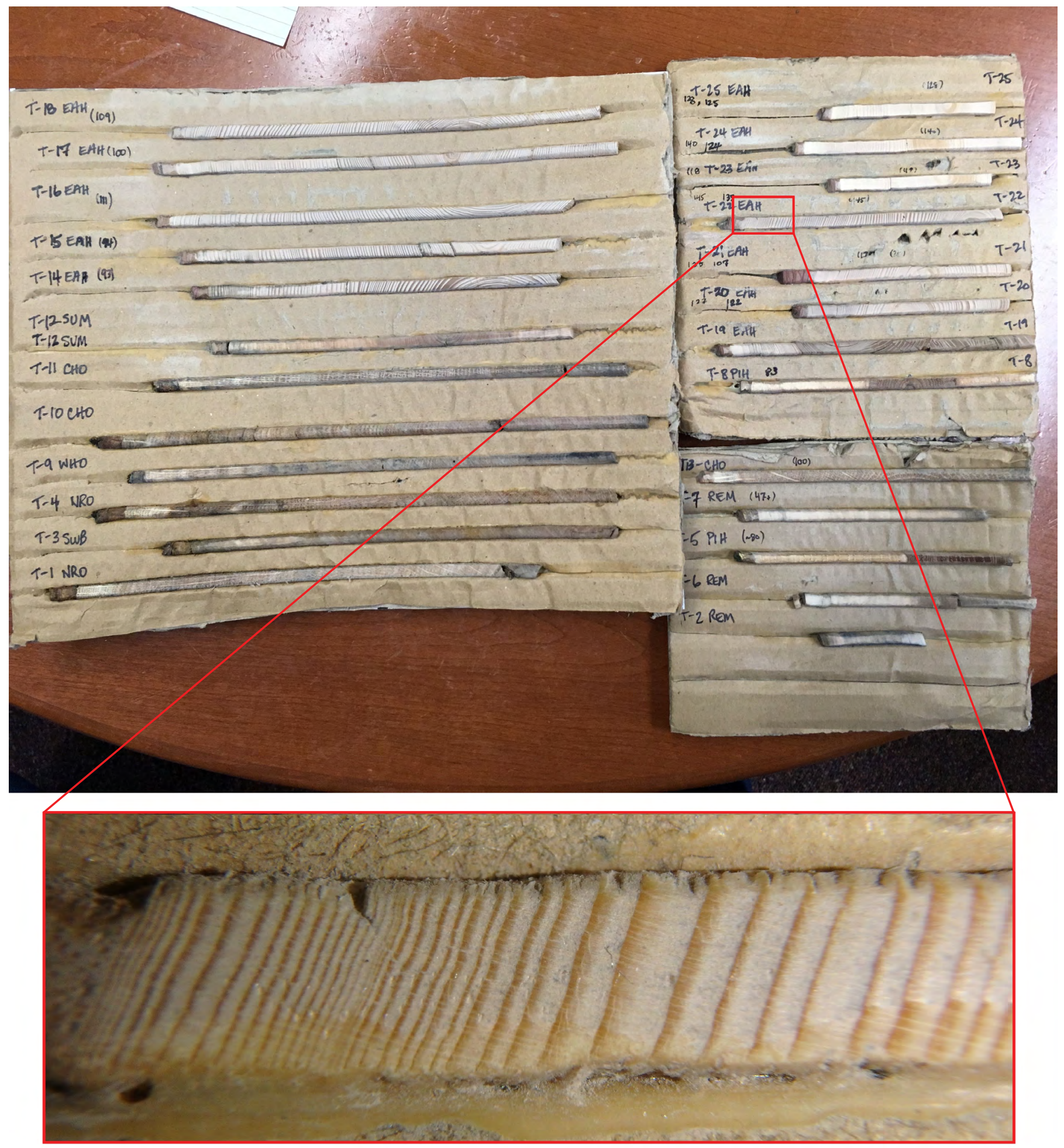

Figure 11. Tree cores collected in 2018 at Harriman State Park, New York. Species shown include red maple (Acer rubrum; REM), sugar maple (A. saccharum; SUM), sweet birch (Betula lenta; SWB), pignut hickory (Carya glabra; PIH), white oak (Quercus alba; WHO), chestnut oak (Q. montana; $\mathrm{CHO}$ ), northern red oak (Q. rubra; NRO), and eastern hemlock (Tsuga canadensis; EAH). The T-[x] numbers indicate the tree the core came from, and the numbers in parentheses are the estimated minimum ages of the trees. 
Table 8. Species, diameter at breast height, and estimated minimum age of all trees cored at Harriman State Park, New York, in 2018.

[Ages are conservative because rings of annual growth were often indistinct, many cores did not go through the center of the tree, and cores were not extracted at ground level. dbh, diameter at breast height; cm, centimeter]

\begin{tabular}{cclcc}
\hline $\begin{array}{c}\text { Tree } \\
\text { number }\end{array}$ & $\begin{array}{c}\text { Species } \\
\text { code }\end{array}$ & $\begin{array}{c}\text { Species common } \\
\text { name }\end{array}$ & $\begin{array}{c}\text { Dbh } \\
\text { (cm) }\end{array}$ & $\begin{array}{c}\text { Estimated } \\
\text { minimum age }\end{array}$ \\
\hline T1 & NRO & Northern red oak & 39.6 & 104 \\
T2 & REM & Red maple & 19.8 & - \\
T3 & SWB & Sweet birch & 33.8 & - \\
T4 & NRO & Northern red oak & 37.1 & 100 \\
T5 & PIH & Pignut hickory & 14.5 & 94 \\
T6 & REM & Red maple & 18.3 & 96 \\
T7 & REM & Red maple & 30.0 & $60 *$ \\
T8 & PIH & Pignut hickory & 11.4 & 83 \\
T9 & WHO & White oak & 24.4 & 104 \\
T10 & CHO & Chestnut oak & 36.1 & 117 \\
T11 & CHO & Chestnut oak & 34.8 & 117 \\
T12 & SUM & Sugar maple & 15.2 & 120 \\
T13 & CHO & Chestnut oak & 19.3 & 100 \\
T14 & EAH & Eastern hemlock & 21.6 & 93 \\
T15 & EAH & Eastern hemlock & 25.2 & 94 \\
T16 & EAH & Eastern hemlock & 23.9 & 113 \\
T17 & EAH & Eastern hemlock & 21.6 & 130 \\
T18 & EAH & Eastern hemlock & 22.9 & 107 \\
T19 & EAH & Eastern hemlock & 11.2 & 107 \\
T20 & EAH & Eastern hemlock & 9.7 & 125 \\
T21 & EAH & Eastern hemlock & 11.9 & 116 \\
T22 & EAH & Eastern hemlock & 17.0 & 137 \\
T23 & EAH & Eastern hemlock & 9.4 & 119 \\
T24 & EAH & Eastern hemlock & 9.4 & 132 \\
T25 & EAH & Eastern hemlock & 10.9 & 128 \\
\hline This & & Ex & \\
\hline
\end{tabular}

${ }^{*}$ This estimate is an exceptionally conservative minimum age because a portion of the core was not intact upon collection.

\section{Discussion}

Nearly 50 years of regulated deer harvest resulted in forests with characteristics indicating substantial recovery from chronic herbivory. The case sites, those with ongoing deer management, exhibited more ground layer vegetation that included greater cover of tree seedlings and herbaceous plants and less cover of species avoided by deer (for example, Pennsylvania sedge and nonnative species) than control sites, those without deer management. Six species of special concern (common ladyfern [Athyrium filix-femina], evergreen woodfern, marginal woodfern [Dryopteris marginalis], downy rattlesnake plantain [Goodyera pubescens], and southern arrowwood [Viburnum dentatum]) were only observed on case sites during our surveys. More importantly, a well-developed subcanopy layer of small trees, saplings, and tall shrubs among case sites indicates a reduction in deer herbivory and a high potential for sapling recruitment to the canopy of the future forest. Forests of Harriman and Bear Mountain State Parks have not shown substantial recruitment of trees into the canopy for more than 100 years. American beech composed the greatest seedling coverage on sites without deer harvest. Due to its high shade, sprouting ability, tolerance and low preference as deer browse, American beech can be a major obstacle to regenerating a diverse, upland forest composition (Sage and others, 2003; Bashant and others, 2005). It should be noted that other vegetation community types of Harriman and Bear Mountain State Parks were not included in our surveys and do not provide the environmental conditions necessary for American beech proliferation.

The low sapling density and subcanopy tree species diversity observed at Harriman and Bear Mountain State Parks are indicative of high white-tailed deer browsing pressure. Similarly, high densities of white-tailed deer were associated with low sapling abundance and low tree species diversity in the regeneration layer of a northern hardwood forest in Wisconsin (Powers and Nage, 2009) and Ontario, Canada (Tanentzap and others, 2011). In addition, the composition of subcanopy constituents at case sites indicates that the future forest is not likely to resemble the extant forest of today. For example, American beech, a legacy of chronic deer herbivory (Sage and others, 2003; Rawinski, 2016) is an important constituent of the subcanopy in both case (ranked fifth) and control (ranked second) sites. We observed a small number of oak saplings on case sites and even fewer on control sites, indicating a trickle of oak recruitment, though the ratio of oaks to maples and birches remains low among all sites. Even if historical disturbance regimes (for example, coppice forestry, fire) were restored at Harriman and Bear Mountain State Parks, oak seedlings and saplings would continue to be browsed by deer (Abrams, 1992; Healy, 1997; Arthur and others, 2015; Blossey and others, 2017), leading to widespread oak regeneration failure (Marquis and others, 1976; Brose and others, 2008; Dey, 2014) without deer management.

Greater ground layer vegetation cover like we documented at case sites is not surprising after a reduction in deer herbivory, though it can take a very long time to develop (Duffy and Meier, 1992; Royo and others, 2010; Waller, 2014; Webster and others, 2016). Pendergast and others (2016) suggested a lag time of more than a decade for areas suffering from chronic herbivory. In their exclosure experiment in northwestern Pennsylvania, understory community composition began to diverge between protected and exposed plots after 5 years, but the number of plant species observed remained low even after 11 years. Royo and others (2010) observed greater shrub and herbaceous cover in hardwood forests after deer herbivory reduction, though they did not detect a difference in number of species. Goetsch and others (2011) 
observed substantial declines in number of species and diversity in ground and shrub layers in Pennsylvania as a result of deer browsing. However, due to dispersal limitation, low seed viability, and highly specific growing conditions, some herbaceous species may never fully recover from chronic deer browsing without assistance (Webster and others, 2005a, 2016; Royo and others, 2010).

We observed significantly greater cover of Pennsylvania sedge among control than case sites, demonstrating its unpalatability to deer (Carson and others, 2005; Holdsworth and others, 2007). Interestingly, we did not find a difference in either cover or occurrence of hay-scented fern between case and control sites, nor were they prognostic of recovery in the analysis. Other forest community understories dominated by hay-scented fern have shown fewer species of other herbs (Rooney and Dress, 1997) and reductions in germination, survival, and growth of desirable canopy tree seedlings (Horsley and Marquis, 1983). In our study, however, cover and occurrence of hay-scented fern were quite low (about 1 percent) among both case and control sites. Unlike plots with dense fern cover, graminoid-covered understory plots can recover after a reduction in deer herbivory without manual removal (Horsley and Marquis, 1983).

White-tailed deer herbivory is an important contributor to the invasion of several nonnative, invasive plant species into forests (Williams and Ward, 2006; Eschtruth and Battles, 2009b; Blossey and Gorchov, 2017), including two we documented in our surveys: Japanese barberry and Japanese stiltgrass. We encountered these species almost exclusively in moist soils at low elevations, which may prevent them from spreading rapidly in the dry oak forests at high elevations. Interestingly, our analysis demonstrated that case sites, in addition to having less cover of nonnative species, also have less proportional occurrence of native plant species. We attribute this seemingly contradictory result to sampling variation; we sampled three times as many plots on control sites than case sites and had greater opportunity to encounter additional species as a consequence. Nevertheless, the signaling of a decrease in percent cover of nonnatives in response to lower herbivory is consistent with findings from other studies on some of the same sites we studied (Nuzzo and others, 2017).

Other factors not directly addressed in this report may also affect forest composition in Harriman and Bear Mountain State Parks. Herbivorous small mammals affect understory composition and cover, though their effects were secondary to those of white-tailed deer in another study examining the effects of chronic herbivory on forest vegetation (Forrester and others, 2006). In a hardwood forest in Pennsylvania, acorn insects and rodents also partially contributed to oak regeneration failure (Marquis and others, 1976). Invasive earthworms alter natural forest processes by accelerating leaf litter decomposition, reducing soil humus, and potentially affecting seedling establishment (Ward and others, 2013). We directly observed earthworms in three plots on the West Point Military Reservation, where several studies have discussed the negative and interactive effects of deer and earthworms on forest vegetation (Dávalos and others, 2015; Blossey and others, 2017; Nuzzo and others, 2017). In forests in Wisconsin where deer and earthworms co-occur, the effects of earthworms on the rate of plant community change were subdued in areas with lower deer densities (Holdsworth and others, 2007).

As an alternative to a long-term exclosure study, the case-control study design we modified is less expensive and more expedient to administer. We acknowledge that without careful matching between case and control plots, the power of this design would have been seriously compromised. Unlike a typical epidemiological application, our case-control study design includes an intervention (that is, deer harvest). In that sense, our study design is a hybrid between case-control and dose-response (Berry, 1980). We did not attempt to estimate the dose-response, however, due to uncertainty in the details about deer harvest on case sites. Using proper case-control vernacular, the shared exposure between cases and controls is chronic herbivory from the distant past, so the outcome is indicated by the presence (that is, case) or lack (that is, control) of deer harvest. In our usage, the reduction in herbivory brought about through deer harvest elicits forest recovery.

Surprisingly, we were able to distinguish substantial recovery indicators from herbs and other ground layer vegetation between case and control sites, each of which is highly variable (Waller, 2014; Habeck and Schultz, 2015). Apparently, ground layer responses to reduced deer herbivory that had accumulated during several decades were sufficient to distinguish cases from controls. Exclosure studies are rarely conducted for durations long enough to allow these differences to manifest (see Nuttle and others, 2014; Pendergast and others, 2016; Webster and others, 2016). Another equally surprising result was that proportional occurrence was as prognostic as estimated foliar cover, which has important implications for future surveys - recording species presence in subplots is substantially faster than estimating foliar cover (Elzinga and others, 1998). For sites less affected by deer herbivory, however, the advantage of time saved by eliminating cover estimation may not be as compelling due to much greater variation in foliar cover among layer constituents.

\section{Management Implications}

A capacity for recovery is possible in the forests of Harriman and Bear Mountain State Parks should a reduction in deer herbivory be sustained into the future. Without targeted management intervention, however, the forests of the future will not resemble the extant forest. In response to reduced herbivory, future forests may be expected to exhibit increased cover of tree seedlings, small shrubs, and common herbs; decreased cover of nonnative and interfering plants; and a well-developed subcanopy of tall shrubs, small trees and saplings with greater overall diversity. The average age of existing canopy trees in these parks exceeds 100 years and is a relic of coppice forestry that supported the iron smelting and 
brickyard industries of the past. Thin soils and rugged topography make wind throw an important disturbance factor in these forests - a hazard that increases with each passing year. Without a substantial recruitment of saplings that can accede to the canopy during the next century, the structure and composition of the extant forest can be expected to change radically.

To ensure reliable and desirable tree species recruitment, herbivory control (that is, exclusion and deer population reduction) could be incorporated into a management plan to successfully regenerate forest stands of a desired composition (Behrend and others, 1970; Horsley and others, 2003; Steiner and others, 2008; Lesser and others, 2019). The potential for reestablishment of sensitive, understory herbs could be assessed by examining the soil seed bank for viability (Forrester and Leopold, 2006). A more thorough understanding of effects of deer herbivory on canopy recruitment from other forest communities could be undertaken to assess the efforts required to achieve desired forest conditions (Ward and others, 2013) in Harriman and Bear Mountain State Parks. If unmanaged, interfering vegetation may continue to inhibit oak seedling establishment (Lorimer and others, 1994; George and Bazzaz, 1999; Oswalt and others, 2004; Steiner and others, 2008), even after reductions in deer density (de la Cretaz and Kelty, 2002; Tanentzap and others, 2011; Bourg and others, 2017). In an experiment in the greater Washington, D.C., area, oaks only increased after white-tailed deer exclusion and interfering plant removal (Bourg and others, 2017). After deer exclusion, Bourg and others (2017) also observed significant declines in Japanese stiltgrass, a common invasive species found in our study sites. According to Lesser and others (2019), even moderate deer reductions in the lower Hudson Valley could increase forest regeneration.

Recovery of forests to desired conditions will likely take decades after reduction of deer herbivory (Latham and others, 2005; Nuttle and others, 2011; Pendergast and others, 2016; Webster and others, 2016). A time lag is expected between reduction in herbivory and recruitment of desired canopy species into the subcanopy or canopy forest layers (Carson and others, 2005), partially due to the capricious nature of mast crops (McShea and Schwede, 1993; Healy, 1997). After removing interfering vegetation and reducing deer populations in the Adirondacks, areas previously dominated by undesirable vegetation began exhibiting signs of forest recovery after 5 years (Sage and others, 2003). To initiate desired recruitment of oaks in forests of Harriman and Bear Mountain State Parks, a combination of reductions in deer herbivory and removal of interfering vegetation may be necessary (Coomes and others, 2003; Dávalos and others, 2015; Nuzzo and others, 2015, 2017; Vose and Elliott, 2016). Maintenance of reduced deer herbivory is crucial to sustain natural forest regeneration long after initiation (Behrend and Patric, 1969).

\section{References Cited}

Abrams, M.D., 1992, Fire and development of oak forests: BioScience, v. 42, no. 5, p. 346-353.

Abrams, M.D., 2003, Where has all the white oak gone?: BioScience, v. 53, no. 10, p. 927-939.

Abrams, M.D., and Nowacki, G.J., 2008, Native Americans as active and passive promoters of mast and fruit trees in the eastern USA: The Holocene, v. 18, no. 7, p. 1123-1137.

Ahrens, W.H., Cox, D.J., and Budhwar, G., 1990, Use of the arcsine and square root transformations for subjectively determined percentage data: Weed Science, v. 38, nos. 4-5, p. $452-458$.

Alexander, H.D., and Arthur, M.A., 2010, Implications of a predicted shift from upland oaks to red maple on forest hydrology and nutrient availability: Canadian Journal of Forest Research, v. 40, no. 4, p. 716-726.

Arthur, M.A., Blankenship, B.A., Schörgendorfer, A, Loftis, D.L., and Alexander, H.D., 2015, Changes in stand structure and tree vigor with repeated prescribed fire in an Appalachian hardwood forest: Forest Ecology and Management, v. 340, p. 46-61.

Augustine, D.J., and McNaughton, S.J., 1998, Ungulate effects on the functional species composition of plant communities: herbivore selectivity and plant tolerance: The Journal of Wildlife Management, v. 62, no. 4, p. 1165-1183.

Averill, K.M., Mortensen, D.A., Smithwick, E.A., Kalisz, S., McShea, W.J., Bourg, N.A., Parker, J.D., Royo, A.A., Abrams, M.D., Apsley, D.A., Blossey, B., Boucher, D.H., Caraher, K.L., DiTommaso, A., Johnson, S.E., Masson, R., and Nuzzo, V.A., 2017, A regional assessment of whitetailed deer effects on plant invasion: AoB Plants, v. 10, no. 1, p. 1-22.

Ball, B.A., Bradford, M.A., and Hunter, M.D., 2009, Nitrogen and phosphorus release from mixed litter layers is lower than predicted from single species decay: Ecosystems, v. 12, no. 1, p. $87-100$.

Ballantyne, J., 2000, Bambi is destroying our forests-A case study in vegetation regeneration following a clear-cut: New York, Columbia University, Barnard College Master's thesis, $112 \mathrm{p}$.

Barringer, K., and Clemants, S.E., 2003, The vascular flora of Black Rock Forest, Cornwall, New York: The Journal of the Torrey Botanical Society, v. 130, no. 4, p. 292-308. 
Bashant, A.L., Nyland, R.D., Engelman, H.M., Bohn, K.K., Versotek, J.M., Donoso, P.J., and Nissen, R.L., Jr., 2005, The role of interfering plants in regenerating hardwood stands of northeastern North America: Orono, University of Maine, $63 \mathrm{p}$.

Beasom, S.L., and Haucke, H.H., 1975, A comparison of four distance sampling techniques in South Texas live oak mottes: Journal of Range Management, v. 28, no. 2, p. 142-144.

Behrend, D.F., and Patric, E.F., 1969, Influence of site disturbance and removal of shade on regeneration of deer browse: The Journal of Wildlife Management, v. 33, no. 2, p. 394-398.

Behrend, D.F., Mattfeld, G.F., Tierson, W.C., and Wiley, J.E., III, 1970, Deer density control for comprehensive forest management: Journal of Forestry, v. 68, no. 11, p. 695-700.

Berry, G., 1980, Dose-response in case-control studies: Journal of Epidemiology and Community Health, v. 34, no. 3, p. 217-222.

Blossey, B., Dávalos, A., and Nuzzo, V., 2017, An indicator approach to capture impacts of white-tailed deer and other ungulates in the presence of multiple associated stressors: AoB Plants, v. 9, no. 5, p. 1-16.

Blossey, B., and Gorchov, D.L., 2017, Introduction to the special issue-Ungulates and invasive species; Quantifying impacts and understanding interactions: AoB Plants, v. 9, no. 6, p. 1-6.

Bonnell, S.M., 1990, Soil survey of Rockland, New York: U.S. Department of Agriculture, Soil Conservation Service report, $193 \mathrm{p}$.

Bourg, N.A., McShea, W.J., Herrmann, V., and Stewart, C.M., 2017, Interactive effects of deer exclusion and exotic plant removal on deciduous forest understory communities: AoB Plants, v. 9, no. 5, p. 1-16.

Brose, P.H., Gottschalk, K.W., Horsley, S.B., Knopp, P.D., Kochenderfer, J.N., McGuinness, B.J., Miller, G.W., Ristau, T.E., Stoleson, S.H., and Stout, S.L., 2008, Prescribing regeneration treatments for mixed-oak forests in the midAtlantic region: U.S. Department of Agriculture General Technical Report NRS-33, 108 p.

Brown, J.A., Lockwood, J.L., Avery, J.D., Burkhalter, J.C., Aagaard, K., and Fenn, K.H., 2019, Evaluating the longterm effectiveness of terrestrial protected areas - A 40-year look at forest bird diversity: Biodiversity and Conservation, v. 28 , no. 4 , p. $811-826$.

Carlson, M.D.A., and Morrison, R.S., 2009, Study design, precision and validity in observational studies: Journal of Palliative Medicine, v. 12, no. 1, p. 77-82.
Carson, W.P., Banta, J.A., Royo, A.A., and Kirschbaum, C., 2005, Plant communities growing on boulders in the Allegheny National Forest: evidence for boulders as refugia from deer and as a bioassay of overbrowsing: Natural Areas Journal, v. 25, no. 1, p. 10-18.

Chapman, J.I., and McEwan, R.W., 2016, Thirty years of compositional change in an old-growth temperate forest-The role of topographic gradients in oak-maple dynamics: PLOS One, v. 11, no. 7, e0160238, 17 p., accessed June 23, 2019, at https://doi.org/10.1371/journal.pone.0160238.

Comiskey, J.A., and Wakamiya, S.M., 2011, Mid-Atlantic network forest vegetation monitoring-2007 to 2010: U.S. National Park Service Natural Resource Technical Report NPS/MIDN/NRTR_-2011/471, 36 p.

Connelly, N.A., Smallidge, P.J., Goff, G.R., and Curtis, P.D., 2010, Foresters' perceptions of forest regeneration and possible barriers to regeneration in New York State: Cornell University Human Dimensions Research Unit Series 10-2, $37 \mathrm{p}$.

Coomes, D.A., Allen, R.B., Forsyth, D.M., and Lee, W.G., 2003, Factors preventing the recovery of New Zealand forests following control of invasive deer: Conservation Biology, v. 17, no. 2, p. 450-459.

Côté, S.D., Rooney, T.P., Tremblay, J., Dussault, C., and Waller, D.M., 2004, Ecological impacts of deer overabundance: Annual Review of Ecology, Evolution, and Systematics, v. 35, p. 113-147.

Cottam, G., and Curtis, J.T., 1956, The use of distance measures in phytosociological sampling: Ecology, v. 37, no. 3, p. $451-460$.

Dávalos, A., Nuzzo, V., and Blossey, B., 2015, Interactive effects of deer, earthworms, and non-native plants on rare forest plant recruitment: Biological Conservation, v. 187, p. 173-181.

Day, F.P., Phillips, D.L., and Monk, C.D., 1988, Forest communities and patterns, in Swank, W.T., and Crossley, D.A, eds., Forest hydrology and ecology at Coweeta: New York, Springer, p. 141-149.

de la Cretaz, A.L., and Kelty, M.J., 2002, Development of tree regeneration in fern-dominated forest understories after reduction of deer browsing: Restoration Ecology, v. 10, no. 2 , p. 416-426.

DeJong, T.M., 1975, A comparison of three diversity indices based on their components of richness and evenness: Oikos, v. 26 , no. 2 , p. $222-227$. 
Dey, D., 2002, The ecological basis for oak silviculture in eastern North America, in McShea, W.J., and Healy, W.M., eds., Oak forest ecosystems-Ecology and management for wildlife: Baltimore, Md., Johns Hopkins University Press, p. 60-79.

Dey, D.C., 2014, Sustaining oak forests in eastern North America-Regeneration and recruitment, the pillars of sustainability: Forest Science, v. 60, no. 5, p. 926-942.

Duffy, D.C., and Meier, A.J., 1992, Do Appalachian herbaceous understories ever recover from clearcutting?: Conservation Biology, v. 6, no. 2, p. 196-201.

Duguay, J., and Farfaras, C., 2011, Overabundant suburban deer, invertebrates, and the spread of an invasive exotic plant: Wildlife Society Bulletin, v. 35, no. 3, p. 243-251.

Edinger, G.J., Evans, D.J., Gebauer, S., Howard, T.G., Hunt, D.M., and Olivero, A.M., 2014, Ecological communities of New York state (2d ed.): Albany, N.Y., Natural Heritage Program, $173 \mathrm{p}$.

Ejigou, A., 1996, Power and sample size for matched casecontrol studies: Biometrics, v. 52, no. 3, p. 925-933.

Elliott, K.J., and Vose, J.M., 2011, The contribution of the Coweeta Hydrologic Laboratory to developing an understanding of long-term (1934-2008) changes in managed and unmanaged forests: Forest Ecology and Management, v. 261 , no. 5 , p. $900-910$.

Elliott, K.J., Miniat, C.F., Pederson, N., and Laseter, S.H., 2015, Forest tree growth response to hydroclimatic variability in the southern Appalachians: Global Change Biology, v. 21 , no. 12 , p. $4627-4641$.

Elzinga, C.L., Salzer, D.W., and Willoughby, J.W., 1998, Measuring and monitoring plant populations: U.S. Bureau of Land Management Technical Reference 1730-1, 496 p.

Eschtruth, A.K., and Battles, J.J., 2009a, Acceleration of exotic plant invasion in a forested ecosystem by a generalist herbivore: Conservation Biology, v. 23, no. 2, p. 388-399.

Eschtruth, A.K., and Battles, J.J., 2009b, Assessing the relative importance of disturbance, herbivory, diversity, and propagule pressure in exotic plant invasion: Ecological Monographs, v. 79, no. 2, p. 265-280.

Evans, D.J., and Krahling, H., 2004, Ecological community delineations of selected state parks, New York state: Albany, New York Natural Heritage Program data, accessed March 25, 2004, at http://gis.ny.gov/gisdata/inventories/ details.cfm?DSID=1241.

Evans, D.J., and VanLuven, D.E., 2007, Biodiversity in New York's state park system-Summary of findings: Albany, New York State Department of Environmental Conservation, $105 \mathrm{p}$.
Fei, S., and Steiner, K.C., 2007, Evidence for increasing red maple abundance in the eastern United States: Forest Science, v. 53 , no. 4 , p. $473-477$.

Forrester, J.A., and Leopold, D.J., 2006, Extant and potential vegetation of an old-growth maritime Ilex opaca forest: Plant Ecology, v. 183, no. 2, p. 349-359.

Forrester, J.A., Leopold, D.J., and Underwood, H.B., 2006, Isolating the effects of white-tailed deer on the vegetation dynamics of a rare maritime American holly forest: The American Midland Naturalist, v. 156, no. 1, p. 135-150.

Frazer, G.W., Canham, C.D., and Lertzman, K.P., 1999, Gap light analyzer (GLA) - Imaging software to extract canopy structure and gap light transmission from true-colour fisheye photographs; User's manual and program documentation, version 2.0: Simon Fraser University and Institute of Ecosystem Studies, $36 \mathrm{p}$.

George, L.O., and Bazzaz, F.A., 1999, The fern understory as an ecological filter-Emergence and establishment of canopy-tree seedlings: Ecology, v. 80, no. 3, p. 833-845.

Glitzenstein, J.S., Canham, C.D., McDonnell, M.J., and Streng, D.R., 1990, Effects of environment and land-use history on upland forests of the Cary Arboretum, Hudson Valley, New York: Bulletin of the Torrey Botanical Club, v. 117 , no. 2 , p. 106-122.

Goetsch, C., Wigg, J., Royo, A.A., Ristau, T., and Carson, W.P., 2011, Chronic overbrowsing and biodiversity collapse in a forest understory in Pennsylvania-Results from a 60 year-old deer exclusion plot: Journal of the Torrey Botanical Society, v. 138, no. 2, p. 220-224.

Habeck, C.W., and Schultz, A.K., 2015, Communitylevel impacts of white-tailed deer on understorey plants in North American forests-A meta-analysis: AoB Plants, v. 7, plv119, 12 p., accessed June 24, 2019, at https://doi.org/10.1093/aobpla/plv119.

Hanberry, B.B., Dey, D.C., and He, H.S., 2012, Regime shifts and weakened environmental gradients in open oak and pine ecosystems: PLOS One, v. 7, no. 7, e41337, 16 p., accessed June 26, 2019, at https://doi.org/10.1371/ journal.pone.0041337.

Healy, W.M., 1997, Influence of deer on the structure and composition of oak forests in central Massachusetts, in McShea, W.J., Underwood, H.B., and Rapoole, J.R., eds., The science of overabundance-Deer ecology and population management: Washington, D.C., Smithsonian Institute Scholarly Press, p. 249-266.

Ho, D.E., Imai, K., King, G., and Stuart, E.A., 2011, MatchIt-Nonparametric preprocessing for parametric causal inference: Journal of Statistical Software, v. 42, no. 8, p. 1-28. 
Holdsworth, A.R., Frelich, L.E., and Reich, P.B., 2007, Effects of earthworm invasion on plant species richness in northern hardwood forests: Conservation Biology, v. 21, no. 4, p. 997-1008.

Holm, J.A., Thompson, J.R., McShea, W.J., and Bourg, N.A., 2013, Interactive effects of chronic deer browsing and canopy gap disturbance on forest successional dynamics: Ecosphere, v. 4, no. 11, article 144, 23 p., accessed June 24, 2019, at https://doi.org/10.1890/ES13-00223.1.

Homer, C.G., Dewitz, J.A., Yang, L., Jin, S., Danielson, P., Xian, G., Coulston, J., Herold, N.D., Wickham, J.D., and Megown, K., 2015, Completion of the 2011 national land cover database for the conterminous United States-Representing a decade of land cover change information: Photogrammetric Engineering and Remote Sensing, v. 81, no. 5, p. 345-354.

Horsley, S.B., and Marquis, D.A., 1983, Interference by weeds and deer with Allegheny hardwood reproduction: Canadian Journal of Forest Research, v. 13, no. 1, p. 61-69.

Horsley, S.B., Stout, S.L., and DeCalesta, D.S., 2003, Whitetailed deer impact on the vegetation dynamics of a northern hardwood forest: Ecological Applications, v. 13, no. 1, p. $98-118$.

Hosmer, D., and Lemeshow, S., 2000, Applied logistic regression ( $2 \mathrm{~d}$ ed.): New York, John Wiley and Sons Inc., 392 p.

Hudson, E., 1983, Deer hunt halted in Harriman Park: New York Times, January 30, p. 26.

Jelaska, S.D., Antonić, O., Božić, M., Križan, J., and Kušan, V., 2006, Responses of forest herbs to available understory light measured with hemispherical photographs in silver fir-beech forest in Croatia: Ecological Modelling, v. 194, nos. 1-3, p. 209-218.

Jenkins, L.H., Jenkins, M.A., Webster, C.R., Zollner, P.A., and Shields, J.M., 2014, Herbaceous layer response to 17 years of controlled deer hunting in forested natural areas: Biological Conservation, v. 175, p. 119-128.

Kain, M., Battaglia, L., Royo, A., and Carson, W.P., 2011, Over-browsing in Pennsylvania creates a depauperate forest dominated by an understory tree-Results from a 60 -yearold deer exclosure: Journal of the Torrey Botanical Society, v. 138 , no. 3 , p. $322-326$.

Kalisz, S., Spigler, R.B., and Horvitz, C.C., 2014, In a longterm experimental demography study, excluding ungulates reversed invader's explosive population growth rate and restored natives: Proceedings of the National Academy of Sciences, v. 111, no. 12, p. 4501-4506.
Keiser, A.D., Knoepp, J.D., and Bradford, M.A., 2013, Microbial communities may modify how litter quality affects potential decomposition rates as tree species migrate: Plant and Soil, v. 372, nos. 1-2, p. 167-176.

Kilheffer, C.R., Underwood, H.B., Ries, L., Raphael, J., and Leopold, D.J., 2019, Effects of white-tailed deer (Odocoileus virginianus) exclusion on plant recovery in overwash fans after a severe coastal storm: AoB Plants, v. 11 , no. 5, plz059, 9 p., accessed October 31, 2019, at https://doi.org/10.1093/aobpla/plz059.

Klos, R.J., Wang, G.G., Bauerle, W.L., and Rieck, J.R., 2009, Drought impact on forest growth and mortality in the southeast USA-An analysis using Forest Health and Monitoring data: Ecological Applications, v. 19, no. 3, p. 699-708.

Knoepp, J.D., Reynolds, B.C., Crossley, D.A., and Swank, W.T., 2005, Long-term changes in forest floor processes in southern Appalachian forests: Forest Ecology and Management, v. 220, nos. 1-3, p. 300-312.

LaPaix, R., Freedman, B., and Patriquin, D., 2009, Ground vegetation as an indicator of ecological integrity: Environmental Review, v. 17, p. 249-265.

Largay, E., and Sneddon, L.A., 2007, An approach to quantifying desired forest conditions at Valley Forge National Park: U.S. National Park Service Technical Report NPS/NER/ NRTR-2007/082, 88 p.

Latham, R.E., Beyea, J., Benner, M., Dunn, C.A., Fajvan, M.A., Freed, R.R., Grund, M., Horsley, S.B., Rhoads, A.F., and Shissler, B.P., 2005, Managing white-tailed deer in forest habitat from an ecosystem perspective-Pennsylvania case study: Harrisburg, Penn., Audubon Pennsylvania and Pennsylvania Habitat Alliance, 20 p.

Lawton, R.O., and Putz, F.E., 1988, Natural disturbance and gap-phase regeneration in a wind-exposed tropical cloud forest: Ecology, v. 69, no. 3, p. 764-777.

Leopold, A., Sowls, L.K., and Spencer, D.L., 1947, A survey of over-populated deer ranges in the United States: The Journal of Wildlife Management, v. 11, no. 2, p. 162-177.

Lesser, M.R., Dovciak, M., Wheat, R., Curtis, P., Smallidge, P., Hurst, J., Kramer, D., Roberts, M., and Frair, J., 2019, Modelling white-tailed deer impacts on forest regeneration to inform deer management options al landscape scales: Forest Ecology and Management, v. 448, p. 395-408.

Lorimer, C.G., Chapman, J.W., and Lambert, W.D., 1994, Tall understory vegetation as a factor in the poor development of oak seedlings beneath mature stands: Journal of Ecology, v. 82 , no. 2 , p. $227-237$. 
Maher, N., 1994, Changes in the park-A study of the ecological and cultural transformations associated with the creation of Bear Mountain State Park: The Hudson Valley Regional Review, v. 11, p. 1-22.

Maher, N., 1999, A very pleasant place to build a towne on?-An environmental history of land preservation in New York's Hudson Highlands: The Hudson Valley Regional Review, v. 16, p. 21-40.

Mann, C.J., 2003, Observational research methods; Research design II; Cohort, cross sectional, and case-control studies: Emergency Medicine Journal, v. 20, no. 1, p. 54-60.

Marquis, D.A., and Brenneman, R., 1981, The impact of deer on forest vegetation in Pennsylvania: U.S. Department of Agriculture General Technical Report NE-65, 11 p.

Marquis, D.A., Eckert, P.L., and Roach, B.A., 1976, Acorn weevils, rodents, and deer all contribute to oak-regeneration difficulties in Pennsylvania: U.S. Department of Agriculture Research Paper NE-356, 8 p.

McCabe, R.E., and McCabe, T.R., 1984, Of slings and arrows-An historical retrospection, in Halls, L.K., ed., White-tailed deer-Ecology and management: Harrisburg, Penn., Stackpole Books, p. 19-27.

McCormick, L.H., Groninger, J.W., and Penrod, K.A., 1992, Colonization of central Pennsylvania oak forests by hay-scented fern: Auburn University Proceedings, v. 2, p. 143-146.

McEwan, R.W., Dyer, J.M., and Pederson, N., 2011, Multiple interacting ecosystem drivers: toward an encompassing hypothesis of oak forest dynamics across eastern North America: Ecography, v. 34, no. 2, p. 244-256.

McIntosh, R.P., 1962, The forest cover of the Catskill Mountain Region, New York, as indicated by land survey records: American Midland Naturalist, v. 68, no. 2, p. 409-423.

McShea, W.J., and Schwede, G., 1993, Variable acorn crops: responses of white-tailed deer and other mast consumers: Journal of Mammalogy, v. 74, no. 4, p. 999-1006.

McWilliams, W.H., Westfall, J.A., Brose, P.H., Dey, D.C., D’Amato, A.W., Dickinson, Y.L., Fajvan, M., Kenefic, L.S., Kern, C.C., Laustsen, K.M., Lehman, S.L., Morin, R.S., Ristau, T.E., Royo, A.A., Stoltman, A.M., and Stout, S.L., 2018, Sub-continental scale patterns of large-ungulate herbivory and synoptic review of restoration management implications for midwestern and northeastern forests: U.S. Department of Agriculture General Technical Report NRS-182, $32 \mathrm{p}$.
Moon, F.F., 1910, Report on the highlands of the Hudson Forest Reservation, in Annual reports of the Forest, Fish, and Game Commissioner for 1907, 1908, 1909: Albany, New York State Forest, Fish, and Game Commission, p. 217-233.

Natural Resources Conservation Service and National Park Service, 2013, Soil survey of upper Delaware national scenic and recreational river, New York and Pennsylvania: Natural Resources Conservation Service and National Park Service data, accessed June 2, 2019, at http://soils.usda.gov/ survey/printed_surveys.

Natural Resources Conservation Service, 2017, Published soil surveys for New York: Natural Resources Conservation Service data, accessed June 3, 2019, at https:/www.nrcs.usda.gov/wps/portal/nrcs/surveylist/soils/ survey/state/?stateId=NY\#.

Natural Resources Conservation Service, 2018, Plants database: Natural Resources Conservation Service data, accessed March 24, 2019, at https://plants.sc.egov.usda.gov/ java/.

New York Natural Heritage Program, 2018, Biotics: Albany, New York State Department of Environmental Conservation data, accessed March 24, 2019, at .

New York State Department of Environmental Conservation, 2009, Inventory of dams: New York State Department of Environmental Conservation data, accessed March 25, 2019, at http://www.dec.ny.gov/maps/nysdams.kmz.

New York State Department of Environmental Conservation, 2018, Annual deer harvest statistics: New York State Department of Environmental Conservation data, accessed May 3, 2019, at https://www.dec.ny.gov/press/113209.html.

New York State Forest, Fish, and Game Commission, 1910, Annual reports of the Forest, Fish, and Game Commissioner for 1907, 1908, 1909: Albany, New York State Forest, Fish, and Game Commission, 407 p.

New York State GIS Clearinghouse, 2018, New York state historic sites and park boundary: New York State GIS Clearinghouse data, accessed January 23, 2019, at http://gis.ny.gov/gisdata/fileserver/?DSID=430\&file= oprhp18.zip.

New York State Office of Parks, Recreation, and Historic Preservation, 2009, Policy on the management of trees and other vegetation in state parks and historic sites: Albany, New York State Parks, Recreation, and Historic Preservation, 4 p.

New York State Office of Parks, Recreation, and Historic Preservation, 2016, New York state open space conservation plan, 2016: Albany, New York State Department of Environmental Conservation, 313 p., appendixes. 
New York State Office of Parks, Recreation, and Historic Preservation, 2018, State Park annual attendance figures by facility_Beginning 2003: New York State Office of Parks, Recreation, and Historic Preservation web page, accessed July 26, 2019, at https://data.ny.gov/Recreation/State-ParkAnnual-Attendance-Figures-by-Facility-B/8f3n-xj78.

Nowacki, G.J., and Abrams, M.D., 2008, The demise of fire and "mesophication" of forests in the eastern United States: BioScience, v. 58, no. 2, p. 123-138.

Nowacki, G.J., and Abrams, M.D., 2015, Is climate an important driver of post-European vegetation change in the eastern United States: Global Change Biology, v. 21, no. 1, p. 314-334.

Nuttle, T., Ristau, T.E., and Royo, A.A., 2014, Long-tern biological legacies of herbivore density in a landscape-scale experiment-Forest understoreys reflect past deer density treatments for at least 20 years: Journal of Ecology, v. 102, no. 1 , p. 221-228.

Nuttle, T., Yerger, E.H., Stoleson, S.H., and Ristau, T.E., 2011, Legacy of top-down herbivore pressure ricochets back up multiple trophic levels in forest canopies over 30 years: Ecosphere, v. 2, no. 1, article 4, 11 p., accessed June 23, 2019, at https://doi.org/10.1890/ES10-00108.1.

Nuzzo, V., Dávalos, A., and Blossey, B., 2015, Invasive earthworms shape forest seed bank composition: Diversity and Distributions, v. 21, no. 5, p. 560-570.

Nuzzo, V., Dávalos, A., and Blossey, B., 2017, Assessing plant community composition fails to capture impacts of whitetailed deer on native and invasive plant species: AoB Plants, v. 9, no. 4, PMC5534022, 18 p., accessed June 23, 2019, at https://doi.org/10.1093/aobpla/plx026.

Olsson, K.S., 1981, Soil survey of Orange County, New York: U.S. Department of Agriculture, Soil Conservation Service Report, 205 p.

Oswalt, C.M., Clatterbuck, W.K., Scharbaum, S.E., and Houston, A.E., 2004, Growth and development of outplanted high-quality northern red oak seedlings and the effects of competing herbaceous production within four overstory treatments-First-year results, in Connor, K.F., ed., Proceedings of the 12th Biennial Southern Silvicultural Research Conference, Biloxi, Miss., February 24-28, 2003: U.S. Department of Agriculture General Technical Report SRS-71, p. 559-564.

Pearce, N., 2016, Analysis of matched case-control studies: The BMJ, v. 352, bmj.i969, 4 p., accessed June 24, 2019, at https://doi.org/10.1136/bmj.i969.
Pendergast, T.H., Hanlon, S.M., Long, Z.M., Royo, A.A., and Carson, W.P., 2016, The legacy of deer overabundanceLong-term delays in herbaceous understory recovery: Canadian Journal of Forest Research, v. 46, no. 3, p. 362-369.

Powers, M.D., and Nagel, L.M., 2009, Pennsylvania sedge cover, forest management and deer density influence tree regeneration dynamics in a northern hardwood forest: Forestry, v. 82 , no. 3 , p. $241-254$.

R Foundation, The, 2015, The R project for statistical computing: The R Foundation website, accessed April 17, 2015, at https://www.r-project.org/.

Rawinski, T., 2016, White-tailed deer in northeastern forestsUnderstanding and assessing impacts: U.S. Department of Agriculture NA-IN-02-14, $31 \mathrm{p}$.

Roberts, D.W., and Cooper, S.V., 1989, Concepts and techniques of vegetation mapping, in Ferguson, D.E., Morgan, P., and Johnson, F.D., eds., Land classifications based on vegetation-Applications for resource management: U.S. Department of Agriculture General Technical Report INT-257, p. 90-96.

Roman, D.T., Novick, K.A., Brzostek, E.R., Dragoni, D., Rahman, F., and Phillips, R.P., 2015, The role of isohydric and anisohydric species in determining ecosystem-scale response to severe drought: Oecologia, v. 179, no. 3, p. 641-654.

Rooney, T.P., and Dress, W.J., 1997, Patterns of plant diversity in overbrowsed primary and mature secondary hemlocknorthern hardwood forest stands: Journal of the Torrey Botanical Society, v. 124, no. 1, p. 43-51.

Rooney, T.P., and Waller, D.M., 2003, Direct and indirect effects of white-tailed deer in forest ecosystems: Forest Ecology and Management, v. 181, nos. 1-2, p. 165-176.

Rose, S., and van der Laan, M.J., 2009, Why match? Investigating matched case-control study designs with causal effect estimation: International Journal of Biostatistics, v. 5, no. 1, p. 1-24.

Royo, A.A., Stout, S.L., DeCalesta, D.S., and Pierson, T.G., 2010, Restoring forest herb communities through landscape-level deer herd reduction-Is recovery limited by legacy effects?: Biological Conservation, v. 143, no. 11, p. 2425-2434.

Russell, E.W.B., 1980, Vegetational change in northern New Jersey from precolonization to the present-A palynological interpretation: Bulletin of the Torrey Botanical Club, v. 107, no. 3, p. 432-446.

Russell, E.W.B., and Schuyler, A.E., 1988, Vegetation and flora of Hopewell Furnace National Historic Site, eastern Pennsylvania: Bartonia, v. 54, p. 124-143. 
Russell, F.L., Zippin, D.B., and Fowler, N.L., 2001, Effects of white-tailed deer (Odocoileus virginianus) on plants, plant populations, and communities-A review: American Midland Naturalist, v. 146, no. 1, p. 1-26.

Russell, M.B., Woodall, C.W., Potter, K.M., Walters, B.F., and Domke, G.M., 2017, Interactions between white-tailed deer density and the composition of forest understories in the northern United States: Forest Ecology and Management, v. 384 , p. 26-33.

Sage, R.W., Jr., Porter, W.F., and Underwood, H.B., 2003, Windows of opportunity-White-tailed deer and the dynamics of northern hardwood forests of the northeastern US: Journal for Nature Conservation, v. 10, no. 4, p. 213-220.

SAS Institute Inc., 2017, SAS/STAT 14.3 user's guide: SAS Institute Inc. website, accessed February 14, 2019, at https://documentation.sas.com/?docsetId=statug\& docsetTarget=titlepage.htm\&docsetVersion= $14.3 \&$ locale $=$ en .

Schuster, W.S.F., Griffin, K.L., Roth, H., Turnbull, M.H., Whitehead, D., and Tissue, D.T., 2008, Changes in composition, structure and aboveground biomass over seventysix years (1930-2006) in the Black Rock Forest, Hudson Highlands, southeastern New York state: Tree Physiology, v. 28 , no. 4 , p. $537-5493$.

Severinghaus, C.W., and Brown, C.P., 1956, History of the white-tailed deer in New York: New York Fish and Game Journal, v. 3, p. 130-167.

Shannon, C.E., and Weaver, W., 1949, The mathematical theory of communication: Urbana, Ill., University of Illinois Press, $144 \mathrm{p}$.

Shirer, R., and Zimmerman, C., 2010, Forest regeneration in New York state: Albany, The Nature Conservancy, Eastern New York Chapter, 25 p.

Sokal, R.R., and Rohlf, F.J., 1995, Biometry-The principles and practices of statistics in biological research ( $3 \mathrm{~d}$ ed.): New York, Freeman, 880 p.

Spurr, S.H., 1956, Forest associations in the Harvard Forest: Ecological Monographs, v. 26, no. 3, p. 245-262.

Steiner, K.C., Finley, J.C., Gould, P.J., Fei, S., and McDill, M., 2008, Oak regeneration guidelines for the central Appalachians: Northern Journal of Applied Forestry, v. 25, no. 1, p. $5-16$.

Szumilas, M., 2010, Explaining odds ratios: Journal of the Canadian Academy of Child Adolescent Psychiatry, v. 19, no. 3, p. 227-229.
Tanentzap, A.J., Bazely, D.R., Koh, S., Timciska, M., Haggith, E.G., Carleton, T.J., and Coomes, D.A., 2011, Seeing the forest for the deer-Do reductions in deer-disturbance lead to forest recovery?: Biological Conservation, v. 144, no. 1, p. $376-382$.

Tierson, W.C., Patric, E.F., and Behrend, D.F., 1966, Influence of white-tailed deer on the logged northern hardwood forest: Journal of Forestry, v. 64, no. 12, p. 801-809.

Tilghman, N.G., 1989, Impacts of white-tailed deer on forest regeneration in northwestern Pennsylvania: The Journal of Wildlife Management, v. 53, no. 3, p. 524-532.

Underwood, H.B., Austin, K.A., Porter, W.F., Burgess, R.L., and Sage, R.W., Jr., 1994, Interactions of whitetailed deer and vegetation at Saratoga National Historic Park: U.S. National Park Service Technical Report NPS/ NAROSS/NRTR/95-28, $32 \mathrm{p}$.

Underwood, H.B., and Porter, W.F., 1997, Reconsidering paradigms of overpopulation of ungulates, in McShea, W.M., Underwood, H.B., and Rappole, J.H., eds., The science of overabundance: Washington, D.C., Smithsonian Institute Press, p. 185-198.

Urbanek, R.E., Nielsen, C.K., Glowacki, G.A., and Preuss, T.S., 2012, White-tailed deer (Odocoileus virginianus Zimm.) herbivory in herbaceous plant communities in northeastern Illinois: Natural Areas Journal, v. 32, no. 1, p. 6-14.

U.S. Geological Survey, 2019, Digital elevation model: U.S. Geological Survey The National Map data, accessed May 6, 2019, at https://viewer.nationalmap.gov/basic/.

Vose, J.M., and Elliott, K.J., 2016, Oak, fire, and global change in the eastern USA-What might the future hold?: Fire Ecology, v. 12, no. 2, p. 160-179.

Waller, D.M., 2014, Effects of deer on forest herb layers, in Gilliam, F.S., ed., The herbaceous layer in forests of eastern North America: New York, Oxford University Press, p. 369-399.

Ward, J.S., Worthley, T.E., Smallidge, P.J., and Bennett, K.P., 2013, Northeast forest regeneration handbook - A guide for forest owners, harvesting practitioners, and public officials: U.S. Department of Agriculture NA-TP-03-06, 66 p.

Wayne, J., 2014, Effects of deer exclosure establishment and subsequent removal on vegetation diversity, tree regeneration, and understory biomass at Black Rock Forest: New York, Columbia University, Barnard College Master's thesis, $36 \mathrm{p}$.

Webster, C.R., Jenkins, M.A., and Rock, J.H., 2005a, Longterm response of spring flora to chronic herbivory and deer exclusion in Great Smoky Mountains National Park, USA: Biological Conservation, v. 125, no. 3, p. 297-307. 
Webster, C.R., Jenkins, M.A., and Rock, J.H., 2005b, Twenty years of forest change in the woodlots of Cades Cove, Great Smoky Mountains National Park: The Journal of the Torrey Botanical Society, v. 132, no. 2, p. 280-292.

Webster, C.R., Rock, J.H., and Jenkins, M.A., 2016, Response of spring flora to nearly two decades of deer exclusion and resurgent woody understories within exclosures: The Journal of the Torrey Botanical Society, v. 144, no. 1, 15-00066.1, 14 p., accessed June 23, 2019, at https://doi.org/10.3159/TORREY-D-15-00066.1.

Weldy, T., Werier, D., and Nelson, A., 2018, New York flora atlas: Albany, New York Flora Association dataset, accessed June 15, 2019, at http://newyork.plantatlas.usf.edu/.
Whitney, G.G., 1994, From coastal wilderness to fruited plain: Cambridge University Press, 486 p.

Widmann, R.H., Crawford, S., Kurtz, C.M., Nelson, M.D., Miles, P.D., Morin, R.S., and Riemann, R., 2015, New York forests, 2012: U.S. Forest Service Resource Bulletin NRS-98, $128 \mathrm{p}$.

Williams, S.C., and Ward, J.S., 2006, Exotic seed dispersal by white-tailed deer in southern Connecticut: Natural Areas Journal, v. 26, no. 4, p. 383-390. 


\section{Appendix 1. Species Encountered in a Study of Hyperabundant White-Tailed Deer in Forested Stands of Harriman and Bear Mountain State Parks, New York}

Table 1.1. Species encountered among control and case plots in a study of white-tailed deer in Forested Stands of Harriman and Bear Mountain State Parks, New York.

[Control and case plots include canopy ("C", $\geq 10.16$-centimeter $[\mathrm{cm}]$ diameter at breast height [dbh]), subcanopy ("S", $<10.16$-cm dbh), and ground cover ("G") forest layers. The list does not include diversity or abundance information and includes presence ("X") or absence of species at least one time among plots surveyed on control and case sites.]

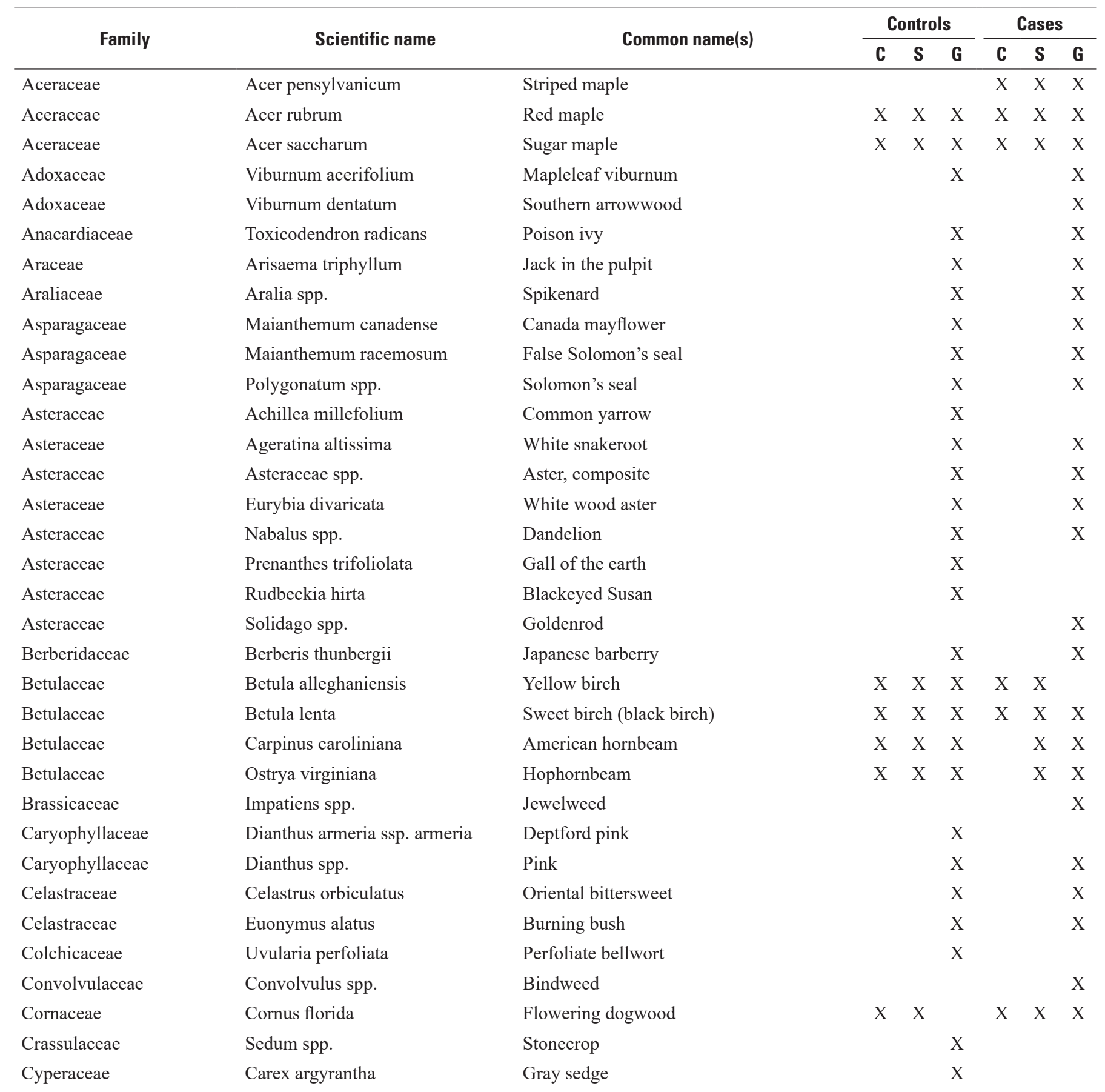


Table 1.1. Species encountered among control and case plots in a study of white-tailed deer in Forested Stands of Harriman and Bear Mountain State Parks, New York.-Continued

[Control and case plots include canopy ("C", $\geq 10.16$-centimeter $[\mathrm{cm}]$ diameter at breast height $[\mathrm{dbh}]$ ), subcanopy ("S", $<10.16$-cm dbh), and ground cover ("G") forest layers. The list does not include diversity or abundance information and includes presence ("X") or absence of species at least one time among plots surveyed on control and case sites.]

\begin{tabular}{|c|c|c|c|c|c|c|c|c|}
\hline \multirow{2}{*}{ Family } & \multirow{2}{*}{ Scientific name } & \multirow{2}{*}{ Common name(s) } & \multicolumn{3}{|c|}{ Controls } & \multicolumn{3}{|c|}{ Cases } \\
\hline & & & C & $\mathbf{S}$ & G & $\mathbf{C}$ & $\mathbf{S}$ & G \\
\hline Cyperaceae & Carex grisea & Inflated narrow-leaf sedge & & & $\mathrm{X}$ & & & \\
\hline Cyperaceae & Carex intumescens & Greater bladder sedge & & & $\mathrm{X}$ & & & \\
\hline Cyperaceae & Carex laxiculmis & Spreading sedge & & & & & & $\mathrm{X}$ \\
\hline Cyperaceae & Carex pensylvanica & Pennsylvania sedge & & & $\mathrm{X}$ & & & $\mathrm{X}$ \\
\hline Cyperaceae & Carex radiata & Eastern star sedge & & & $\mathrm{X}$ & & & $\mathrm{X}$ \\
\hline Cyperaceae & Carex swanii & Swan’s sedge & & & $\mathrm{X}$ & & & $\mathrm{X}$ \\
\hline Cyperaceae & Carex vulpinoidea & Fox sedge & & & $\mathrm{X}$ & & & $\mathrm{X}$ \\
\hline Dennstaedtiaceae & Dennstaedtia punctilobula & Hay-scented fern & & & $\mathrm{X}$ & & & $\mathrm{X}$ \\
\hline Dryopteridaceae & Athyrium filix-femina & Common ladyfern & & & & & & $\mathrm{X}$ \\
\hline Dryopteridaceae & Dryopteris intermedia & Intermediate woodfern & & & & & & $\mathrm{X}$ \\
\hline Dryopteridaceae & Dryopteris marginalis & Marginal woodfern & & & & & & $\mathrm{X}$ \\
\hline Dryopteridaceae & Onoclea sensibilis & Sensitive fern & & & $\mathrm{X}$ & & & $\mathrm{X}$ \\
\hline Dryopteridaceae & Polystichum acrostichoides & Christmas fern & & & $\mathrm{X}$ & & & $\mathrm{X}$ \\
\hline Ericaceae & Chimaphila maculata & Spotted wintergreen & & & $\mathrm{X}$ & & & $\mathrm{X}$ \\
\hline Ericaceae & Gaultheria procumbens & Wintergreen (eastern teaberry) & & & $\mathrm{X}$ & & & $\mathrm{X}$ \\
\hline Ericaceae & Gaylussacia baccata & Black huckleberry & & $\mathrm{x}$ & $\mathrm{X}$ & & & $\mathrm{X}$ \\
\hline Ericaceae & Kalmia latifolia & Mountain laurel & & $\mathrm{x}$ & $\mathrm{X}$ & & $\mathrm{X}$ & $\mathrm{X}$ \\
\hline Ericaceae & Vaccinium angustifolium & Lowbush blueberry & & & $\mathrm{X}$ & & & $\mathrm{X}$ \\
\hline Ericaceae & Vaccinium corymbosum & Highbush blueberry & & $\mathrm{X}$ & $\mathrm{X}$ & & $X$ & $\mathrm{X}$ \\
\hline Fabaceae & Amphicarpaea bracteata & American hogpeanut & & & $\mathrm{X}$ & & & $\mathrm{X}$ \\
\hline Fabaceae & Colutea arborescens & Bladder senna & & & & & & $\mathrm{X}$ \\
\hline Fabaceae & Danthonia spp. & Oatgrass & & & $\mathrm{X}$ & & & $\mathrm{X}$ \\
\hline Fabaceae & Desmodium spp. & Ticktrefoil & & & & & & $\mathrm{X}$ \\
\hline Fabaceae & Trifolium aureum & Golden clover & & & $\mathrm{X}$ & & & \\
\hline Fagaceae & Castanea dentata & American chestnut & $\mathrm{X}$ & & & & $\mathrm{X}$ & \\
\hline Fagaceae & Fagus grandifolia & American beech & $\mathrm{X}$ & $\mathrm{x}$ & $\mathrm{X}$ & $\mathrm{x}$ & $\mathrm{X}$ & $\mathrm{X}$ \\
\hline Fagaceae & Quercus alba & White oak & $\mathrm{X}$ & $\mathrm{x}$ & $\mathrm{X}$ & $\mathrm{X}$ & $\mathrm{X}$ & $\mathrm{X}$ \\
\hline Fagaceae & Quercus coccinea & Scarlet oak & & & & $\mathrm{X}$ & & \\
\hline Fagaceae & Quercus ilicifolia & Bear oak & & & & & $\mathrm{X}$ & \\
\hline Fagaceae & Quercus montana & Chestnut oak & $\mathrm{X}$ & $\mathrm{X}$ & $\mathrm{X}$ & $\mathrm{X}$ & $\mathrm{X}$ & $\mathrm{X}$ \\
\hline Fagaceae & Quercus rubra & Northern red oak & $\mathrm{X}$ & & $\mathrm{X}$ & $\mathrm{X}$ & $\mathrm{X}$ & $\mathrm{X}$ \\
\hline Fagaceae & Quercus velutina & Black oak & $\mathrm{X}$ & & $\mathrm{X}$ & $\mathrm{X}$ & & \\
\hline Geraniaceae & Geranium maculatum & Spotted geranium & & & $\mathrm{X}$ & & & \\
\hline Hamamelidaceae & Hamamelis virginiana & American witchhazel & & $\mathrm{X}$ & $\mathrm{X}$ & & $\mathrm{X}$ & $\mathrm{X}$ \\
\hline Iridaceae & Sisyrinchium angustifolium & Narrowleaf blue-eyed grass & & & $\mathrm{X}$ & & & \\
\hline Juglandaceae & Carya glabra & Pignut hickory & $\mathrm{X}$ & $\mathrm{X}$ & $\mathrm{X}$ & $\mathrm{X}$ & $\mathrm{X}$ & $\mathrm{X}$ \\
\hline Juglandaceae & Carya ovata & Shagbark hickory & $\mathrm{x}$ & & $\mathrm{X}$ & & & $\mathrm{X}$ \\
\hline Juglandaceae & Carya tomentosa & Mockernut hickory & & & & $\mathrm{X}$ & & \\
\hline Juglandaceae & Juglans nigra & Black walnut & $\mathrm{X}$ & & & & & \\
\hline Lamiaceae & Clinopodium vulgare & Wild basil & & & $\mathrm{X}$ & & & \\
\hline
\end{tabular}


Table 1.1. Species encountered among control and case plots in a study of white-tailed deer in Forested Stands of Harriman and Bear Mountain State Parks, New York.-Continued

[Control and case plots include canopy (“C", $\geq 10.16$-centimeter [cm] diameter at breast height [dbh]), subcanopy ("S", $<10.16$-cm dbh), and ground cover ("G") forest layers. The list does not include diversity or abundance information and includes presence ("X") or absence of species at least one time among plots surveyed on control and case sites.]

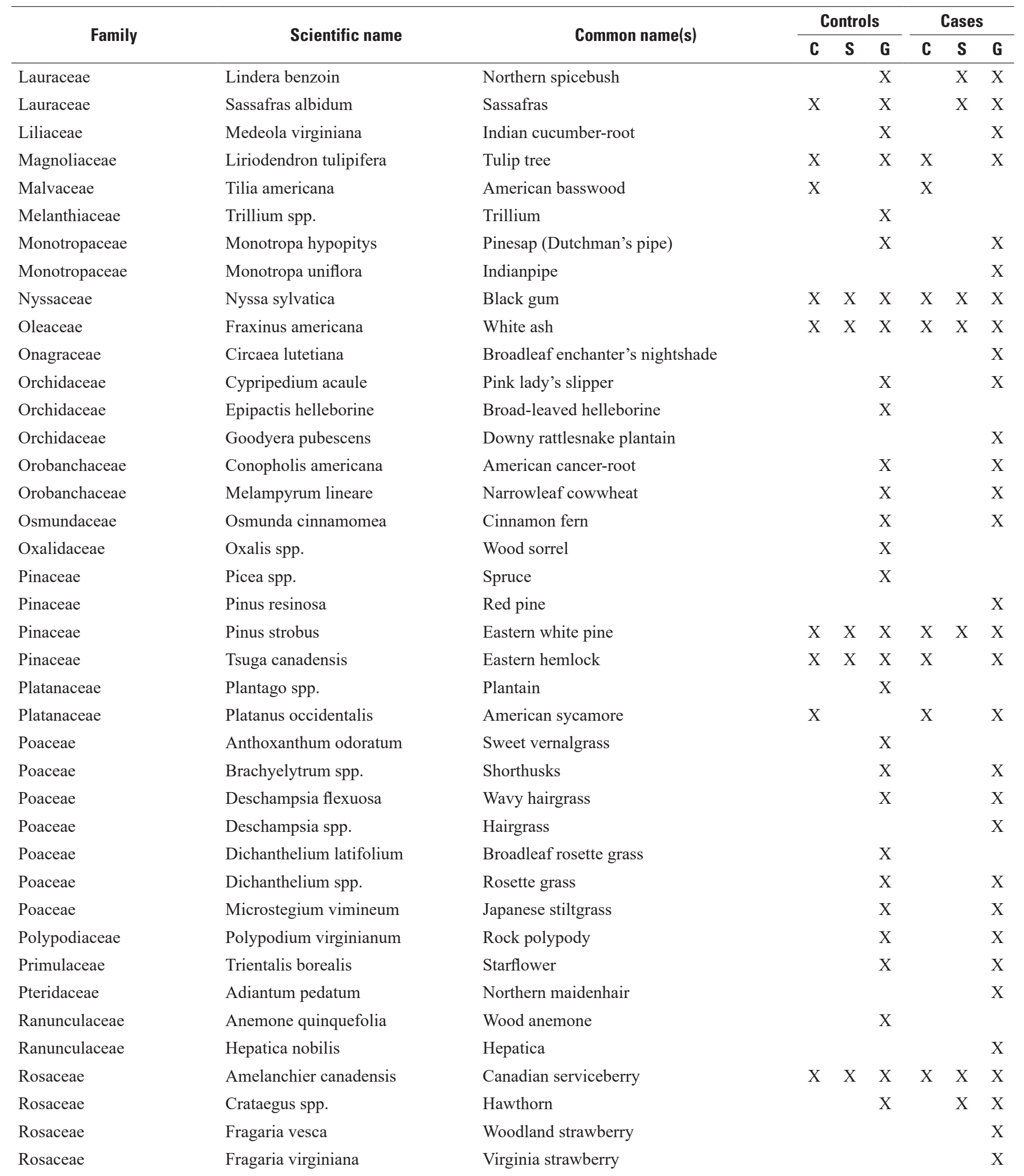


Table 1.1. Species encountered among control and case plots in a study of white-tailed deer in Forested Stands of Harriman and Bear Mountain State Parks, New York.-Continued

[Control and case plots include canopy ("C", $\geq 10.16$-centimeter $[\mathrm{cm}]$ diameter at breast height $[\mathrm{dbh}]$ ), subcanopy ("S", $<10.16$-cm dbh), and ground cover ("G") forest layers. The list does not include diversity or abundance information and includes presence ("X") or absence of species at least one time among plots surveyed on control and case sites.]

\begin{tabular}{|c|c|c|c|c|c|c|c|c|}
\hline \multirow{2}{*}{ Family } & \multirow{2}{*}{ Scientific name } & \multirow{2}{*}{ Common name(s) } & \multicolumn{3}{|c|}{ Controls } & \multicolumn{3}{|c|}{ Cases } \\
\hline & & & C & S & G & C & S & G \\
\hline Rosaceae & Malus spp. & Apple & & & $\mathrm{X}$ & & & \\
\hline Rosaceae & Potentilla spp. & Cinquefoil & & & $\mathrm{X}$ & & & $\mathrm{X}$ \\
\hline Rosaceae & Prunus serotina & Black cherry & & & $\mathrm{x}$ & & $\mathrm{X}$ & $\mathrm{X}$ \\
\hline Rosaceae & Rosa multiflora & Multiflora rose & & & $\mathrm{X}$ & & & $\mathrm{X}$ \\
\hline Rosaceae & Rosaceae spp. & Rose & & & $\mathrm{x}$ & & & \\
\hline Rosaceae & Rubus flagellaris & Northern dewberry & & & $\mathrm{x}$ & & & \\
\hline Rosaceae & Rubus occidentalis & Black raspberry & & & $\mathrm{x}$ & & & \\
\hline Rosaceae & Rubus phoenicolasius & Wineberry & & & $\mathrm{x}$ & & & $\mathrm{X}$ \\
\hline Rosaceae & Rubus spp. & Raspberry & & & $\mathrm{X}$ & & & $\mathrm{X}$ \\
\hline Rubiaceae & Galium spp. & Bedstraw & & & $\mathrm{x}$ & & & $\mathrm{X}$ \\
\hline Rubiaceae & Mitchella repens & Partridgeberry & & & $\mathrm{x}$ & & & $\mathrm{X}$ \\
\hline Salicaceae & Populus grandidentata & Bigtooth aspen & & $\mathrm{X}$ & $\mathrm{x}$ & & & \\
\hline Scrophulariaceae & Chelone glabra & White turtlehead & & & & & & $\mathrm{X}$ \\
\hline Simaroubaceae & Ailanthus altissima & Tree of heaven & & & $\mathrm{X}$ & & & $\mathrm{X}$ \\
\hline Smilacaceae & Smilax rotundifolia & Roundleaf greenbrier & & & $\mathrm{X}$ & & & \\
\hline Staphyleaceae & Staphylea trifolia & American bladdernut & & & & & & $\mathrm{X}$ \\
\hline Thelypteridaceae & Thelypteris noveboracensis & New York fern & & & $\mathrm{X}$ & & & \\
\hline Ulmaceae & Ulmus americana & American elm & & & & & & $\mathrm{X}$ \\
\hline Ulmaceae & Ulmus rubra & Slippery elm & & & $\mathrm{X}$ & & $\mathrm{X}$ & \\
\hline Vitaceae & Parthenocissus quinquefolia & Virginia creeper & & & $\mathrm{X}$ & & & $\mathrm{X}$ \\
\hline Vitaceae & Vitis spp. & Grape & & & $\mathrm{X}$ & & & $\mathrm{X}$ \\
\hline
\end{tabular}



For more information, contact

Director, Patuxent Wildlife Research Center U.S. Geological Survey

12100 Beech Forest Road

Laurel, MD 20708-4039

https://www.usgs.gov/centers/pwrc

Publishing support provided by the Pembroke Publishing Service Center 


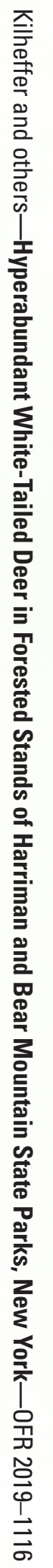

